\title{
Article \\ The Spatial-Temporal Characteristics of Soil Moisture and Its Persistence over Australia in the Last 20 Years
}

\author{
Jiangtao Cai ${ }^{1}$, Tiexi Chen ${ }^{1,2, *}$, Qingyun Yan ${ }^{3}{ }^{-}$, Xin Chen ${ }^{1}$ and Renjie Guo ${ }^{1}$ \\ 1 Collaborative Innovation Center on Forecast and Evaluation of Meteorological Disaster, School of \\ Geographical Sciences, Nanjing University of Information Science \& Technology, Nanjing 210044, China; \\ 20191210001@nuit.edu.cn (J.C.); 20191210002@nuist.edu.cn (X.C.); 20201210003@nuist.edu.cn (R.G.) \\ 2 School of Geographical Sciences, Qinghai Normal University, Xining 810008, China \\ 3 School of Remote Sensing and Geomatics Engineering, Nanjing University of Information \\ Science \& Technology, Nanjing 210044, China; 003257@nuist.edu.cn \\ * Correspondence: txchen@nuist.edu.cn
}

Citation: Cai, J.; Chen, T.; Yan, Q.; Chen, X.; Guo, R. The Spatial-Temporal Characteristics of Soil Moisture and Its Persistence over Australia in the Last 20 Years. Water 2022, 14, 598. https://doi.org/ 10.3390/w14040598

Academic Editors: Kebiao Mao, Chunxiang Shi and Shibo Fang

Received: 24 December 2021

Accepted: 14 February 2022

Published: 16 February 2022

Publisher's Note: MDPI stays neutral with regard to jurisdictional claims in published maps and institutional affiliations.

Copyright: (C) 2022 by the authors. Licensee MDPI, Basel, Switzerland. This article is an open access article distributed under the terms and conditions of the Creative Commons Attribution (CC BY) license (https:// creativecommons.org/licenses/by/ $4.0 /)$.

\begin{abstract}
Persistence is an important feature of soil moisture, which affects many important processes such as land-air interaction and ecohydrological processes. Soil moisture datasets from reanalysis, remote-sensing observations and land surface models have been widely used in various ecohydrological studies, however, due to the complexity of hydrological processes, the essential features of soil moisture such as spatial-temporal characteristics and persistence still need to be further quantified. This study focused on the Australia region and used in situ observation from fourteen International Soil Moisture Network sites to evaluate soil moisture from six gridded products, including satellite remote-sensing records (ESA CCI), output of reanalysis (ERA5-Land) and land surface models (GLDAS and GLEAM). High correlation coefficients between observations and the other soil moisture datasets were gotten. Regional averaged inter-annual variations of soil moisture were relatively large with some dry periods (2002-2010, 2013-2016) and wet periods (2011-2012) indicated by these gridded products. General coherent spatial patterns were found in long-term soil moisture with large differences in the lateral inflow area of the Great Artesian Basin. The coefficient of variation of these soil moisture datasets generally decreased from northwest to southeast, but the enhanced vegetation index coefficient of variation was larger in the southwest corner, northeast (non-coastal areas) and the lateral inflow area. Persistence calculated from various soil moisture datasets had quite large differences compared with measurements. Meanwhile, little coherence was gotten among different surface soil moisture datasets, the persistence of deep soil moisture seemed to be significantly overestimated. Therefore, models still need to improve the temporal characteristics with the persistence rather than the correlation coefficient.
\end{abstract}

Keywords: soil moisture; temporal trends; persistence; precipitation; LSMs

\section{Introduction}

Soil moisture (SM) is one of the essential variables of the terrestrial water cycle, ecohydrology and land-air interactions [1]. Compared with precipitation, SM has a typical characteristic of red noise with memory, also called persistence. SM persistence (SMP) refers to the anomaly duration which usually lasts from days to months. SMP can be calculated by autocorrelation coefficient (AC) methods and is quantified by lag (in days) AC drops below 1/e [2]. SMP plays a vital role [3] in land-air interaction, and the study of SM dynamics and its persistence is of great significance for improving land surface models (LSMs).

As SM involves complex water processes, scientists are committed to continuously improving SM datasets from both observation and simulation. SM data from site observation is sparsely distributed and has poor time continuity, and thus, it is difficult to apply it in large-scale and long-term analysis. With the rapid development of satellite remote-sensing 
technology and SM retrieval algorithms [4], several remote-sensed SM products [5,6] have been developed. Corresponding limitations are also obvious because remote-sensing observation can only catch the surface SM indirectly, therefore, LSMs and reanalysis SM products are also widely applied [7]. SM modeling methods in LSMs usually rely on biophysical processes [8,9], the LSMs outputs have good time continuity and reflect the dynamics at different depths in soil. However, their applicability in different regions remains to be evaluated due to the negligence of lateral flow [10], especially in areas with complicated topographical structure. Different LSMs use various model architectures and driving data, which causes certain differences in different model products; however, they can still verify each other and draw some common conclusions.

The accuracy of these SM datasets from reanalysis, remote sensing and LSMs have been extensively verified with in situ observations [5]. Previous studies have focused more on discussing the response of SM to atmospheric forcing [11] and their causality [12,13] or coupling state [14-16]. The relationship between the SMP and its driver is still not well-known. SMP has a profound impact on subsequent weather and climate conditions through land-air feedback, and it is affected by soil texture, overlying vegetation, and hydro-climatic forcing [17]. Precipitation pulse is the main source of SM, the redistribution of precipitation is affected by topography, soil texture and so on. Different soil textures have different water infiltration rates [18] affecting the vertical flow of soil water, which affects the SMP, while overlying vegetation cover mainly affects subsurface flow (both vertical and horizontal flow) through physical existence of root structure and hydraulic redistribution.

In this study, Australia was chosen as a typical water-limited ecosystem region with high remote sensing SM data quality [19], Australia is also a key region with a water-related global carbon cycle. The objective was to analyze the spatial-temporal characteristics of SM and SMP at different depths in Australia in the past 20 years (2000-2019) based on multisource SM products and to investigate the drivers of surface SMP. Firstly, the performance of surface SM data from different models was evaluated through the observed data from the International Soil Moisture Network (ISMN) sites [20,21]. Then, we studied the spatial pattern of Australian SM through its annual mean, coefficient of variation and amplitude. Meanwhile, the dry-wet interannual trend of the past 20 years was also discussed. Afterwards, SMP at different depths was calculated by time series autocorrelation. The surface SMP in Australia and its driving factors, including precipitation, aridity condition and vegetation cover, was explored.

\section{Materials and Methods}

\subsection{Study Area-Australia}

Here, we choose Australia as the study area. Australia is surrounded by oceans, in the east is the Great Divide, and in the west is the plateau with desert landforms. The Great Artesian Basin with relatively low altitude (Figure 1a) is the largest aquifer system in the world that underlies a large area of central east Australia [22]. The north part of the Great Artesian Basin is a typical lateral inflow area [23] where the lateral subsurface flow is mainly in soil due to soil properties and underlying surface properties. Here, digital elevation model data are from SRTM (The NASA Shuttle Radar Topographic Mission). Australia is a typical water-limited continent. There are about three-quarters drylands area (Figure 1d) where in long lasting arid and semi-arid conditions [24] with low rainfall and high water demand, the landscapes of savanna and grassland account for the majority (Figure 1b). The temporal and spatial distribution of precipitation in drylands of Australia varies a lot, usually concentrated in the summer, which makes this area highly sensitive to global changes $[25,26]$ due to the ecological vulnerability. Water is the main limiting factor for most ecosystems in central and western Australia where in situ observation (Figure 1a) is lacking. 

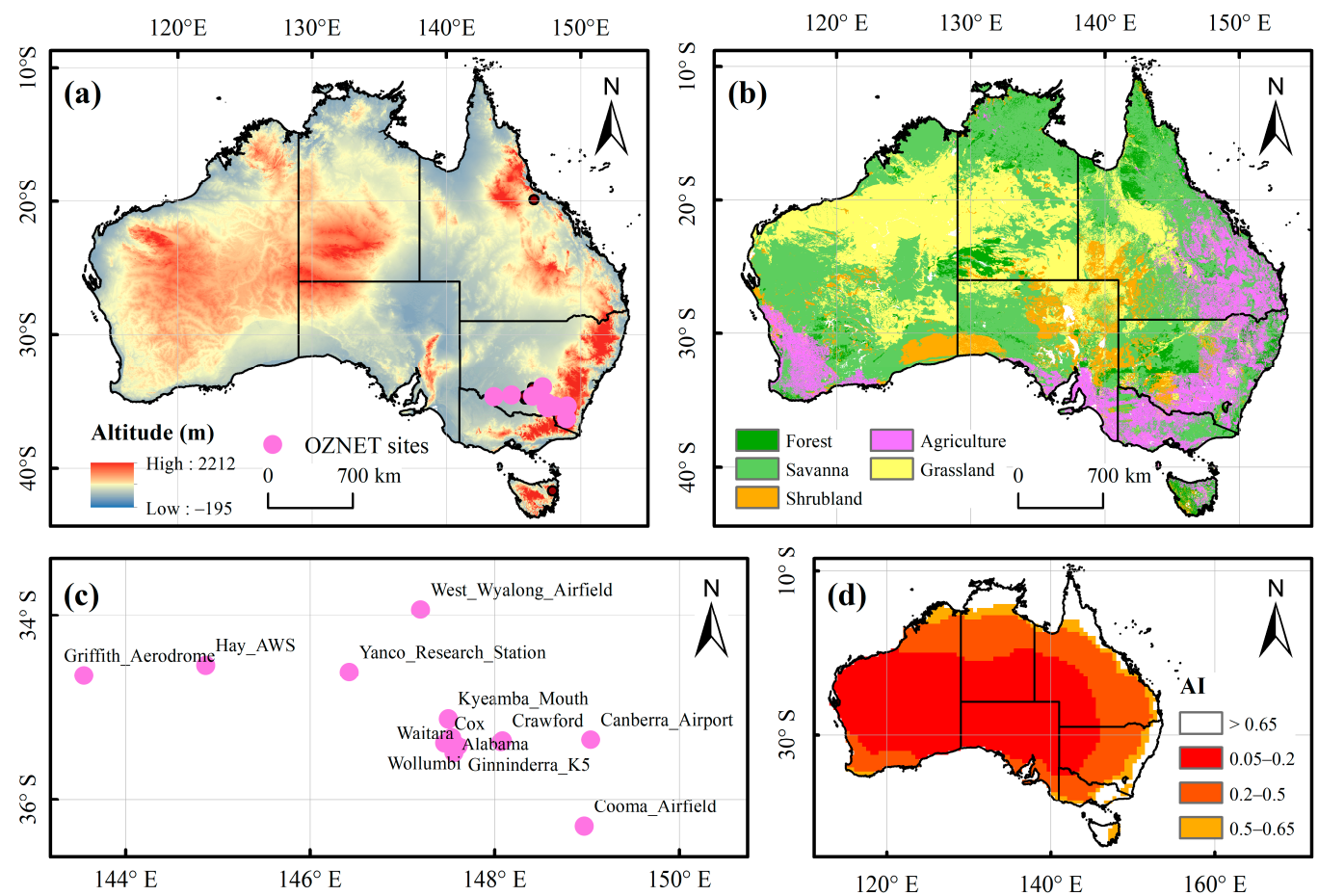

Figure 1. Topography from SRTM (a), vegetation cover ((b), derived from NVIS-MVGs, National Vegetation Information System-Major Vegetation Groups), aridity condition ((d), calculated by $\mathrm{P} / \mathrm{PE})$ and distribution of OZNET network $(\mathbf{a}, \mathbf{c})$ in the study area.

\subsection{Soil Moisture Datasets}

This study used SM data from site observation, remote sensing, LSMs and reanalysis (Table 1) during 2000-2019. We averaged all the SM data to a daily scale for subsequent analysis. The observation SM data was from the Ozark Network Communications (OZNET) in the ISMN. The OZNET network is located in New South Wales (Figure 1a,c), and its SM data mainly covered 4 layers of $0.00-0.08,0.00-0.30,0.30-0.60,0.60-0.90 \mathrm{~m}, \mathrm{SM}$ of all layers was measured with a CS615 or CS616 sensor. Remotely sensed active and passive fusion SM data (ESA CCI soil moisture V04.7) was obtained by the European Space Agency Climate Change Initiative [27,28], reflecting the SM status of the surface layer less than $2 \mathrm{~cm}$ thick [19]. Reanalysis data ERA5-Land [29] was acquired from Copernicus Climate Data Store. Three LSMs SM data, including GLDAS CLSM [30], GLDAS NOAH [31] and GLEAM [32,33] were also used in this study. GLDAS CLSM (GLDAS_CLSM025_DA1_D V2.2) started from 1 February 2003, so we only used it to calculate the SMP which had nothing to do with the length of the time series. The unit of GLDAS SM data is soil weight moisture content $\left(\mathrm{kg} \mathrm{m}^{-2}\right)$, which needed to be converted into soil volume moisture content $\left(\mathrm{m}^{3} \mathrm{~m}^{-3}\right)$ in advance by dividing the soil thickness value. GLEAM is a semi-empirical process-based model. Combining with remote sensing data, it could be treated as a simple LSM that only focuses on terrestrial evapotranspiration (ET) and SM. GLEAM v3.5 has two versions ( $a$ and $b$ ), GLEAM v3.5b data was also only used for SMP analysis. GLEAM v3.5b is mainly based on remotely sensed data, and its vegetation coverage is driven by MOD44B, while GLEAM v3.5a integrates measured, reanalyzed and remotely sensed vegetation optical depth data. More information of the six SM products can be found in Table 1. Fourteen sites that have been continuously exceeded for two years and whose sequence length was an integral multiple of the season were selected during the study period. All the SM datasets were set on a daily scale for subsequent analysis. 
Table 1. Overview of gridded SM datasets used in this study.

\begin{tabular}{|c|c|c|c|c|c|}
\hline Data & Data Type & Layers & Temporal Coverage & $\begin{array}{c}\text { Spatial } \\
\text { Resolution }\end{array}$ & $\begin{array}{c}\text { Temporal } \\
\text { Resolution }\end{array}$ \\
\hline ERA5-Land & Reanalysis & $\begin{array}{l}0.00-0.07 \mathrm{~m}, 0.07-0.28 \mathrm{~m} \\
0.28-1.00 \mathrm{~m}, 1.00-2.89 \mathrm{~m}\end{array}$ & 1950-Present & $0.1^{\circ}$ & $1 \mathrm{~h}$ \\
\hline GLDAS CLSM & Land model & $0.00-0.02 \mathrm{~m}, 0.00-1.00 \mathrm{~m}$ & February 2003-July 2021 & $0.25^{\circ}$ & $1 \mathrm{~d}$ \\
\hline GLDAS NOAH & Land model & $\begin{array}{l}0.00-0.10 \mathrm{~m}, 0.10-0.40 \mathrm{~m}, \\
0.40-1.00 \mathrm{~m}, 1.00-2.00 \mathrm{~m}\end{array}$ & January 2000-July 2021 & $0.25^{\circ}$ & $3 \mathrm{~h}$ \\
\hline GLEAM v3.5a & Land model & $0.00-0.10 \mathrm{~m}, 0.10-1.00 \mathrm{~m}$ & $1980-2020$ & $0.25^{\circ}$ & $1 \mathrm{~d}$ \\
\hline GLEAM v3.5b & Land model & $0.00-0.10 \mathrm{~m}, 0.10-1.00 \mathrm{~m}$ & January 2003-July 2020 & $0.25^{\circ}$ & $1 \mathrm{~d}$ \\
\hline ESA CCI & Remote sensing & $<0.02 \mathrm{~m}$ & $1979-2019$ & $0.25^{\circ}$ & $1 \mathrm{~d}$ \\
\hline
\end{tabular}

\subsection{Other Auxiliary Data}

The monthly precipitation and potential evapotranspiration (PET) data from the Climate Research Unit (CRU TS v4.05) of the University of East Anglia [34] with 0.5 spatial resolution were used to calculate the Aridity Index (AI = precipitation/PET) of the study area. In order to analyze the surface SMP difference with different conditions of aridity, we used AI to define the arid area according to the ratio of the average annual precipitation and the average annual atmospheric evaporation demand (usually use PET as the replacement) [35]. The arid area is usually defined as the area with a range of AI less than $0.65[36,37]$, that is, an area where the average annual potential evapotranspiration is much higher than the annual average precipitation.

Rainfall and vegetation transpiration represent the source and consumer of SM (mostly), respectively. We also used Tropical Rainfall Measuring Mission (TRMM) precipitation data [38] and enhanced vegetation index (EVI) data [19] to assist in judging the state of SM, the relationship between surface SMP and parameters such as precipitation frequencies, precipitation intensity and vegetation index was discussed. The monthly EVI data was derived from the MOD13C2 dataset, with a spatial resolution of $0.05^{\circ} \times 0.05^{\circ}$. Compared with vegetation greenness indexes such as normalized difference vegetation index, EVI was affected less by the atmosphere and soil, whose definition is

$$
\mathrm{EVI}=2.5 \times \frac{\rho_{\text {NIR }}}{1+\rho_{\text {NIR }}+6 \times \rho_{\text {Red }}+7.5 \times \rho_{\text {Blue }}}
$$

where $\rho_{N I R}, \rho_{\text {Red }}, \rho_{\text {Blue }}$ is the reflectivity of near infrared, red and blue band, respectively.

The vegetation cover data comes from Australia's National Vegetation Information System-Main Vegetation Groups (NVIS-MVGs V6.0) [39], with a resolution of $100 \mathrm{~m}$. The original 26 NVIS-MVGs were reclassified into several major groups including forest, savanna, shrubland, agriculture and grassland (Figure 1b), which was used to analyze the difference in the surface SMP under different overlying vegetation types.

\subsection{Methods}

\subsubsection{Pearson Correlation}

The Pearson correlation coefficient (r) reflects the degree of correlation between two variables especially in the scatter plot. This study is based on the Pearson correlation analysis of factors that affect the SMP. Assuming that there are time series $x$ and $y$, the formula of correlation coefficient is:

$$
\mathrm{r}=\frac{\sum_{i=1}^{n}\left(x_{i}-\bar{x}\right)\left(y_{i}-\bar{y}\right)}{\sqrt{\sum_{i=1}^{n}\left(x_{i}-\bar{x}\right)^{2}} \sqrt{\sum_{i=1}^{n}\left(y_{i}-\bar{y}\right)^{2}}}
$$

\subsubsection{Autocorrelation (AC)}

The SMP is defined as the time required for an SM anomaly to dissipate [25], and it is mostly estimated based on the autocorrelation (AC) of the SM time series. AC is used to 
describe the continuity of continuous variables, that is, the correlation between the future value of a variable and its own past value (lagged correlation). AC analysis captures the general time dynamics of SM, which reflects the direct response of SM to hydrological processes. Delworth and Manabe [40] first proposed this indicator, and pointed out that on a large temporal and spatial scale, the time series of SM can be reasonably represented as a red noise process, with low-frequency change characteristics. AC e-folding time scale of SM is used to characterize the SMP, that is, the AC coefficient of SM $\left(r_{k}\right)$ decays exponentially with time, and the SMP is defined as the time it takes for $r_{k}$ to decrease to 1/e (about 0.37). The calculation of $r_{k}$ [2] is based on the Pearson correlation coefficient and can be calculated by:

$$
\mathrm{r}_{\mathrm{k}}=\frac{\sum_{i=1}^{n-k} x_{i} x_{i+k}-(n-k) \bar{x}^{2}}{\sum_{i=1}^{n} x_{i}{ }^{2}-n \bar{x}^{2}}
$$

where $x$ is the time series of observations, $n$ is the total number of observations in the time series, $i$ is the current observation to be analyzed and $k$ is the lag time in days.

\section{Results}

\subsection{Evaluation of the Soil Moisture Data}

SM data from $0-0.08 \mathrm{~m}$ at 10 sites on the Australian OZNET network were applied to evaluate the LSMs and remotely sensed surface SM. In the selected period (Figure A1), the time series of the pixel where the station is located was correlated with the in situ observation based on correlation analysis. We found that the ERA5-Land (0.1 degree) time series is the closest to the observed data, with correlation coefficient above 0.7 at each station (Table 2). At a resolution of 0.25 degrees, the simulation of surface SM by GLEAM $\mathrm{v} 3.5 \mathrm{~b}$ was closest to the in situ data, and the average correlation coefficient of all sites reached 0.82 , only slightly lower than that of the ERA5-Land. The surface SM of CCI and the simulation of surface SM by GLDAS CLSM and NOAH models' average correlation coefficient was also about 0.75 .

Table 2. Correlation coefficients between multi-source surface SM datasets and in situ observational sites.

\begin{tabular}{|c|c|c|c|c|c|c|}
\hline Sites & $\begin{array}{c}\text { ERA5-Land } \\
\text { Layer } 1 \\
(0-7 \mathrm{~cm})\end{array}$ & $\begin{array}{c}\text { GLDAS CLSM } \\
\text { Surface } \\
(0-2 \mathrm{~cm})\end{array}$ & $\begin{array}{c}\text { GLDAS } \\
\text { NOAH } \\
(0-10 \mathrm{~cm})\end{array}$ & $\begin{array}{c}\text { GLEAM v3.5a } \\
\text { Surface } \\
(0-10 \mathrm{~cm})\end{array}$ & $\begin{array}{c}\text { GLEAM v3.5b } \\
\text { Surface } \\
(0-10 \mathrm{~cm})\end{array}$ & $\begin{array}{c}\text { ESA CCI } \\
(<2 \mathrm{~cm})\end{array}$ \\
\hline Canberra_Airport & 0.88 & 0.76 & 0.76 & 0.79 & 0.82 & 0.84 \\
\hline Cooma_Airfield & 0.88 & 0.77 & 0.77 & 0.83 & 0.84 & 0.72 \\
\hline Crawford & 0.88 & 0.84 & 0.79 & 0.82 & 0.86 & 0.77 \\
\hline Ginninderra_K5 & 0.89 & 0.85 & 0.81 & 0.89 & 0.88 & 0.74 \\
\hline Griffith_Aerodrome & 0.72 & 0.73 & 0.67 & 0.80 & 0.80 & 0.73 \\
\hline Hay_AWS & 0.71 & 0.68 & 0.69 & 0.73 & 0.73 & 0.65 \\
\hline Rochedale & 0.78 & - & 0.67 & 0.71 & - & 0.70 \\
\hline Waitara & 0.81 & 0.59 & 0.74 & 0.68 & 0.69 & 0.71 \\
\hline West_Wyalong_Airfield & 0.88 & 0.75 & 0.85 & 0.90 & 0.91 & 0.88 \\
\hline Yanco_Research_Station & 0.85 & 0.71 & 0.74 & 0.84 & 0.87 & 0.84 \\
\hline Average & 0.83 & 0.74 & 0.75 & 0.80 & 0.82 & 0.76 \\
\hline
\end{tabular}

\subsection{Temporal and Spatial Characteristics of Soil Moisture in Australia}

From the view of temporal scale, the SM retrieved based on remote sensing in Australia had good consistency with the temporal fluctuation of vegetation and precipitation (Figure A2). The fluctuation of surface SM was much stronger than that of deep SM, which means that the time series of deep SM was smoother than that of surface SM. The multi-layer SM maximum values all appeared in 2011. The inter-annual fluctuations of SM were relatively large, and there were some dry periods (2002-2010, 2013-2016) and wet periods (2011-2012). Different LSMs of SM had different performances. GLEAM simulated the surface SM dryer (Figures 2 and A2), and the distinction between surface and roots in GLEAM was not obvious; while GLDAS simulated deep SM wetter, layers of 10-40 and 

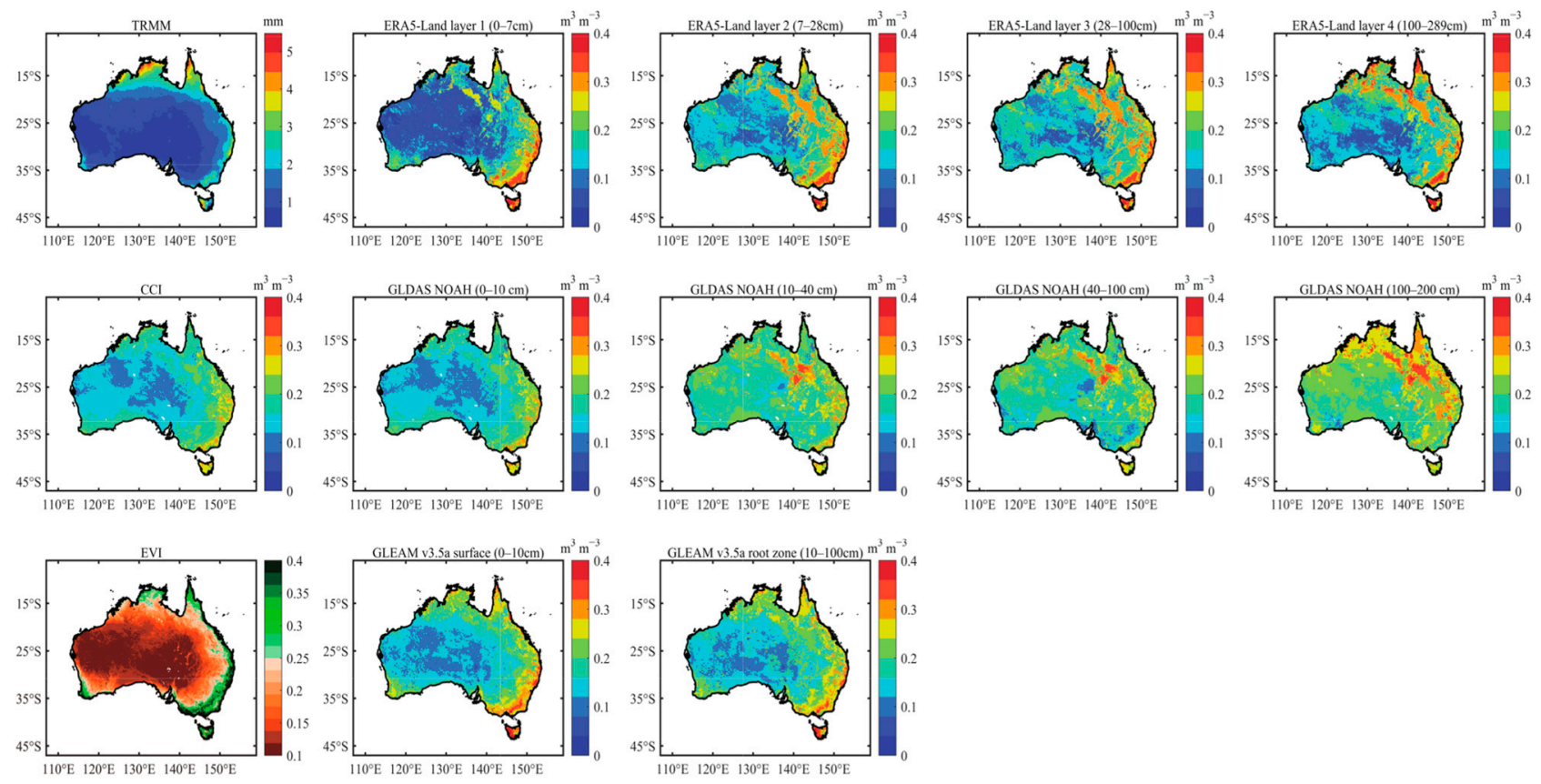

Figure 2. Spatial distribution of annual average SM in Australia from 2000 to 2019 (Columns 2 to 5). From top to bottom of Column 1 represents spatial distribution of annual average remotely sensed precipitation, SM and EVI.

From the perspective of spatial distribution (Figure 3), multi-source SM data all showed that the surface SM in Australia had an obvious drying trend from 2000 to 2019, and the drying area was mainly concentrated in the northwest, which was relatively similar with precipitation. Both ERA5-Land Volumetric soil water layer $4(100-289 \mathrm{~cm})$ and GLDAS NOAH SM $(100-200 \mathrm{~cm})$ showed that the trend of deep SM had significant spatial heterogeneity, the average deep SM in the central plain had shown a slight drying trend over the years, which was opposite to that of the surface.

The spatial patterns of precipitation, SM and vegetation were generally coherent, however, there were some local structural differences, which may be caused by the redistribution of water flow after precipitation (Figure 2). The annual average surface SM spatial pattern of dry-wet simulated by GLDAS NOAH had good consistency with remotely sensed SM from ESA CCI. Due to its finer spatial resolution, ERA5-Land SM data reflected more spatial details and did not simply directly mask water bodies such as ephemeral lakes. Compared with other data, this expressed the SM in the seasonal wetlands in Australia better. The GLEAM model did not show the high SM in lateral inflow area well.

Multiple SM data showed that Australia's annual average surface SM decreased from the east coast and southwest corner to inland. The annual average surface SM in the western desert was lower (below $0.1 \mathrm{~m}^{3} \mathrm{~m}^{-3}$ ), while in northeastern Australia there were two northwest-southeast direction lateral inflow areas with high surface SM (above $0.3 \mathrm{~m}^{3} \mathrm{~m}^{-3}$ ), and the high SM status in the lateral inflow area was also reflected in the deep SM (ERA5-Land, GLDAS NOAH). In addition, northeastern and southeastern Australia also showed a high annual average deep SM.

From the coefficient of variation (CV) of SM (Figure 4), the spatial distribution of surface and deep SM variation was quite different from that of vegetation and precipitation. The northwestern part of the surface SM varied greatly (exceeding 50\%), SM variation decreased from northwest to southeast, and the EVI CV was also large in the lateral inflow area. The large EVI CV in agricultural area such as the Murray River Basin and the southwest corner of Australia indicated that there were still some defects in the model 
simulation of SM over these areas. The CV of deep SM was relatively small compared with that of surface SM, mostly less than $20 \%$, and it decreased as the depth of the soil layer increased.
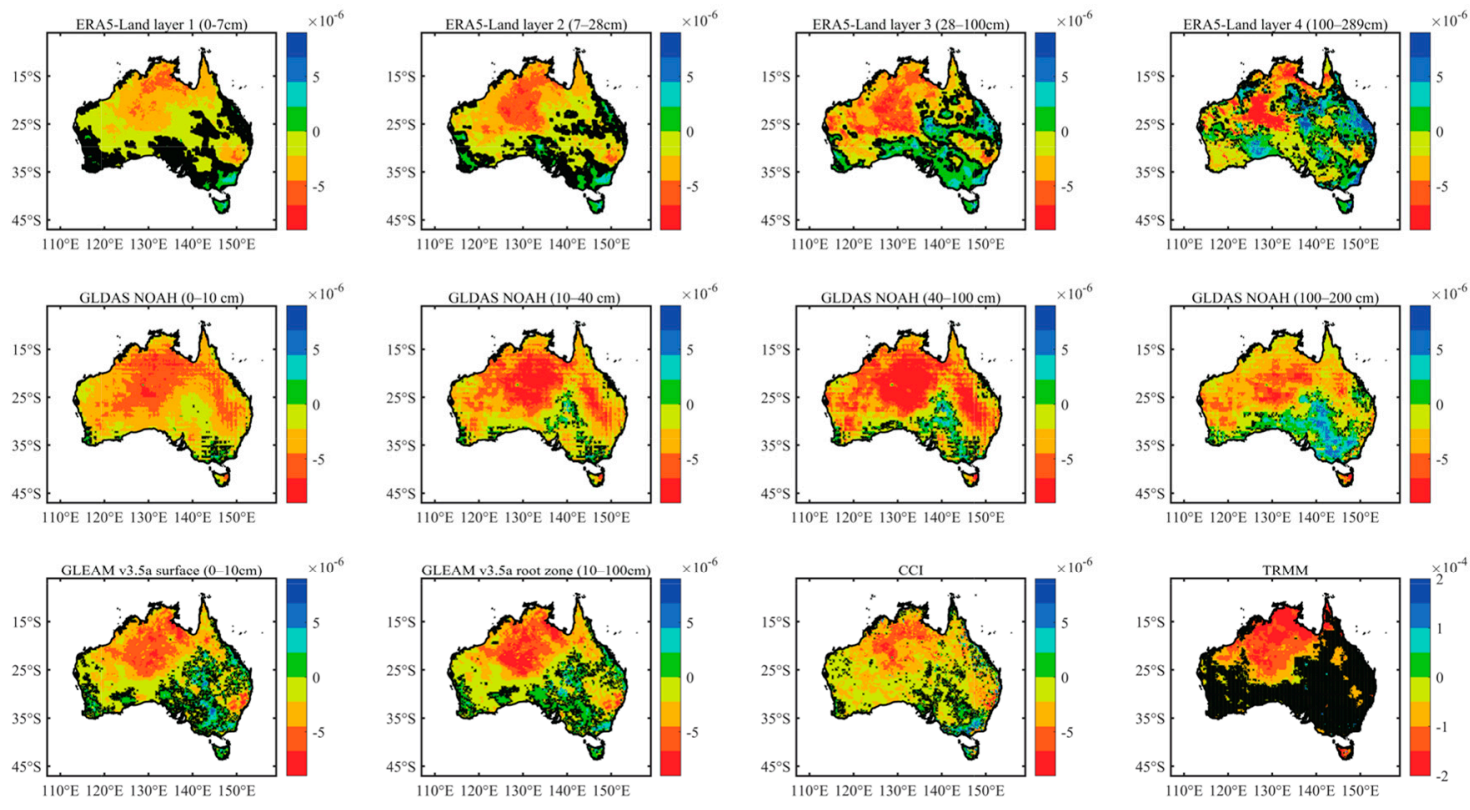

Figure 3. The spatial distribution of SM and precipitation trends from 2000 to 2019. (The black shaded area is the area where the linear trend failed the $95 \%$ significance test).
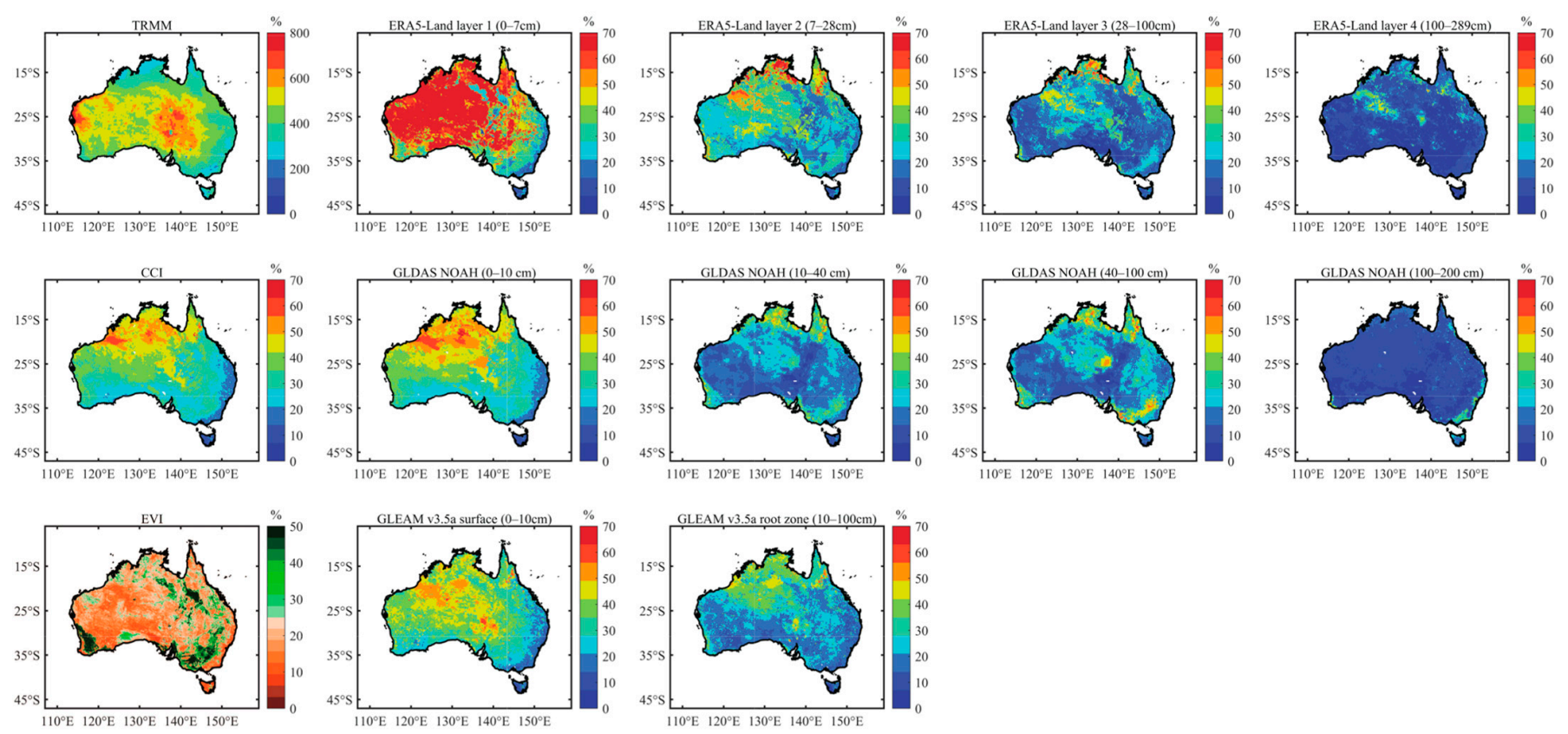

Figure 4. Same as Figure 3, but for coefficient of variation, i.e., (Standard Deviation/Mean) $\times 100 \%$.

\subsection{Soil Moisture Persistence in Australia}

The SMP calculated from the SM observation at 14 ISMN stations (Figure A3) showed that the average SMP of the four-layer soil profile at depths of $0-0.08,0-0.3,0.3-0.6$ and $0.6-0.9 \mathrm{~m}$ were $40,47,61$ and 68 days, respectively (Table 3, Figure A4); the surface SMP did not exceed 59 days. SMP difference of $0.6-0.9 \mathrm{~m}$ was relatively large comparing with surface SMP. Within the depth of 0-0.9 m, the SMP at most sites increased with the increase of soil depth, except two sites where the SMP of the 0.6-0.9 m layer was less than that of the $0.3-0.6 \mathrm{~m}$ layer. 
Table 3. SMP (days) of four layers from 14 in situ observational sites.

\begin{tabular}{ccccc}
\hline Sites & $\mathbf{0 - 0 . 0 8 ~} \mathbf{~}$ & $\mathbf{0 - 0 . 3 ~} \mathbf{~}$ & $\mathbf{0 . 3 - 0 . 6 ~} \mathbf{~}$ & $\mathbf{0 . 6 - 0 . 9 ~} \mathbf{~}$ \\
\hline Alabama & - & 47 & 50 & 55 \\
Canberra_Airport & 43 & 46 & 54 & 83 \\
Cooma_Airfield & 40 & 53 & 56 & 61 \\
Cox & - & 47 & 50 & 50 \\
Crawford & 54 & 54 & 64 & 77 \\
Ginninderra_K5 & 59 & 58 & 56 & 52 \\
Griffith_Aerodrome & 42 & 35 & 40 & 60 \\
Hay_AWS & 27 & - & 129 & 108 \\
Kyeamba_Mouth & - & 38 & 79 & 115 \\
Rochedale & 36 & 50 & 60 & 65 \\
Waitara & 26 & 59 & 61 & 65 \\
West_Wyalong_Airfield & 27 & 27 & 48 & 36 \\
Wollumbi & - & 51 & 51 & 58 \\
Yanco_Research_Station & 45 & 43 & 56 & - \\
\hline All sites average & 40 & 47 & 61 & 68 \\
\hline
\end{tabular}

At the same time, the surface SMP was compared with remotely sensed and LSMs (Table A1, Figure A1), the error of CCI surface SMP was only less than three days at three sites, which indicated that the persistence of CCI was quite accurate. The average error of GLDAS CLSM was the smallest, only 6.5 days, which indicated balanced simulation. GLEAM V3.5a had the largest average error in days, and surface SMP had an average error of 15 days.

The spatial patterns of SMP were further calculated with all gridded SM datasets. The SMP in Australia had obvious spatial heterogeneity, especially in deep SM. Multiple SM datasets showed that the surface SMP was within 60 days (about two months, Figure 5), which was consistent with the site observation results. The places with high surface SMP were mainly in the agricultural areas in the north, southwest and southeast. The surface SMP in the western desert area was poor, within 10 days. SMP of ERA5-Land $(0-7 \mathrm{~cm})$ was underestimated. Compared with CLSM and GLEAM, NOAH and ERA5-Land root zone SMP were more durable, it was exceeding 600 days in most areas, which was obviously problematic. The spatial difference of SM in the fourth layer of ERA5-land was very large.
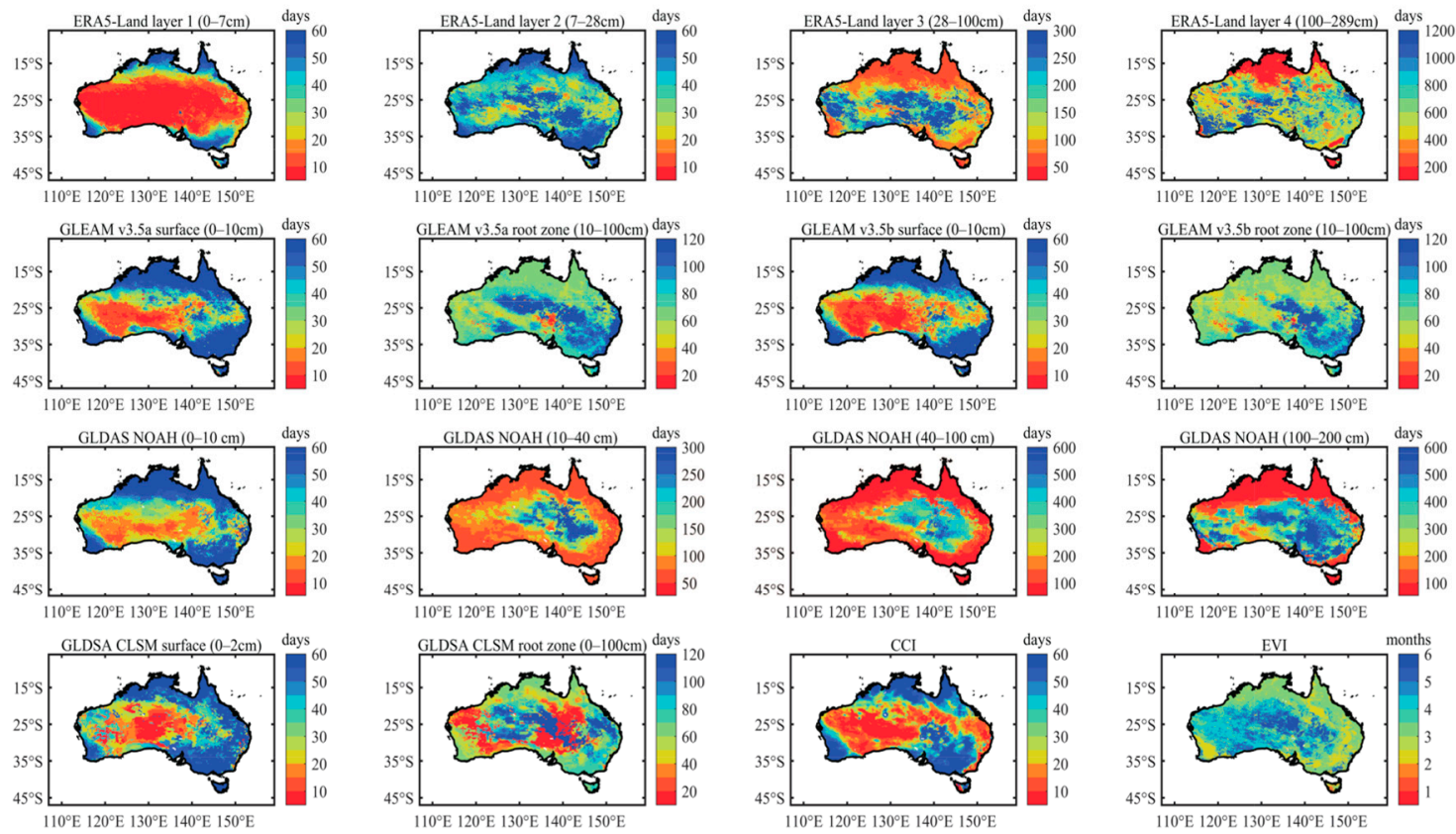

Figure 5. SMP in different depths based on multiple SM datasets and EVI persistence. 


\section{Discussion}

\subsection{The Wet and Dry Condition Indicated by SM}

A large body of research demonstrates that the surface SM in the drylands around the world is continuously decreasing [41-44]. Australia plays an important role in the global water and carbon cycle and is very sensitive to global changes. Most of the estimates in the Intergovernmental Panel on Climate Change report [45] indicated that there will be more frequent and severe droughts in Australia in the future. SM is an important indicator of dry-wet characteristics. Exploring the dynamic characteristics and persistence of SM is essential for accurately predicting future droughts. Multiple SM data showed that the surface SM in Australia showed a significant drying trend from 2000 to 2019 (Figure 3) overall. The multi-year maximum values of EVI, precipitation and SM all appeared in 2011 (Figure A2). This strong water and carbon anomaly was related to La Niña [44], which had been the strongest for more than 90 years since 1917-2011. Xie et al. [46,47] used the GRACE standard surface water storage anomalies product to analyze the changes in continental surface water storage during the extreme hydrological climate in Australia from 2002 to 2017 and summarized this period as the "Big Dry" of the 2002-2009 period. Although these data have certain differences, they can capture the drought and humid period characteristics of the study area as a whole.

\subsection{Possible Factors Affecting Surface SMP}

The changes of SM always start from the shallow layer and advance to the deep layer. Surface SM plays a vital role in the hydrological and ecological processes of the land surface and determines the changes of deep SM [48]. The surface SMP is affected by many factors such as soil texture, precipitation and evaporation, and has obvious spatial distribution characteristics. Here, we discuss the following factors: precipitation frequency (PF, the percentage of precipitation days $(>0.5 \mathrm{~mm})$ to the total number of days), precipitation intensity (PI, the ratio of total precipitation to the number of precipitation days), the aridity condition and vegetation status.

\subsubsection{Relationship with Precipitation}

As an important hydroclimatic forcing element, precipitation is the main source of SM [13]. SM-precipitation feedback has different driving mechanisms when the SM value is high or low. The feedback between precipitation and SM is spatially heterogeneous, has large uncertainties and is difficult to quantify [49]. In drylands, precipitation fluctuates greatly, and short-term extreme events account for a large proportion of total precipitation [50]. Usually, precipitation frequency is the main determinant of the sustainability of SM, and differences in land cover and soil texture have secondary effects [17]. As the frequency of precipitation increases, the increase in surface SMP is S-shaped (Figure 6), reflecting the two ways that precipitation affects surface SMP: 1 . When the PF is small $(<0.1)$, the increase in precipitation cannot replenish the soil water shortage due to longterm drought, so the persistence is not increased; 2 . After PF increases to a certain value $(>0.2)$, precipitation leads the SM in a stable and saturated state; when PF is between 0.1 and 0.2 , the influence of precipitation frequency on the surface SMP is random, meaning that other factors affect the surface SMP mainly at this condition. In addition, the surface SMP increases with increasing precipitation intensity (Figure A5). 

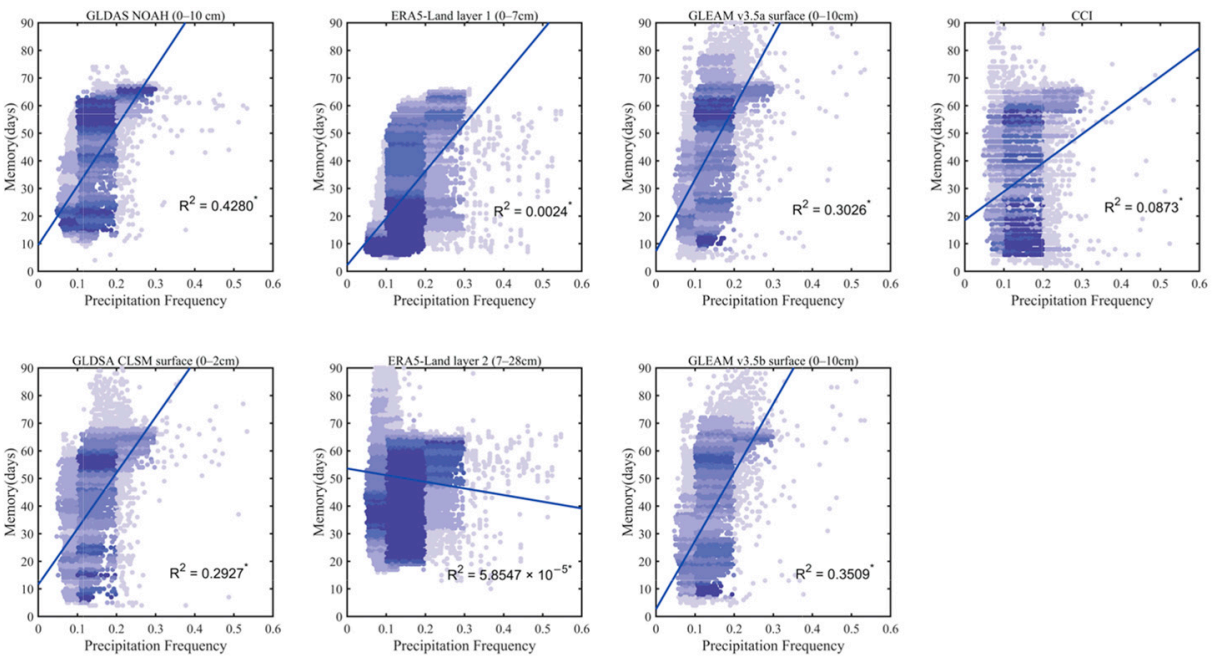

Figure 6. Scatterplots of surface SMP versus precipitation frequency. Among them, $\mathrm{R}$ is the correlation coefficient, ${ }^{*}$ indicating that the correlation coefficient passes the $95 \%$ significance test; the blue solid line is the linear fitting line.

\subsubsection{Relationship with Aridity}

The aridity index quantifies the wet and dry climate in a given location. The SMP is closely related to the degree of aridity, and excessively moist or arid soil is not conducive to the land-air feedback [51]. The relationship between the SMP and aridity index is close to logarithmic (Figure 7). As the aridity index decreases, the degree of SMP increases. Our results demonstrated that vegetation is scarce in drylands, and surface SM is only supplemented by a small amount of precipitation and then quickly evaporates. Its persistence should be the same as precipitation, and the duration of persistence is very short. In humid areas, precipitation is sufficient, and surface SM is stable, so the persistence is longer. This conclusion is consistent with the outcome of McColl [52].
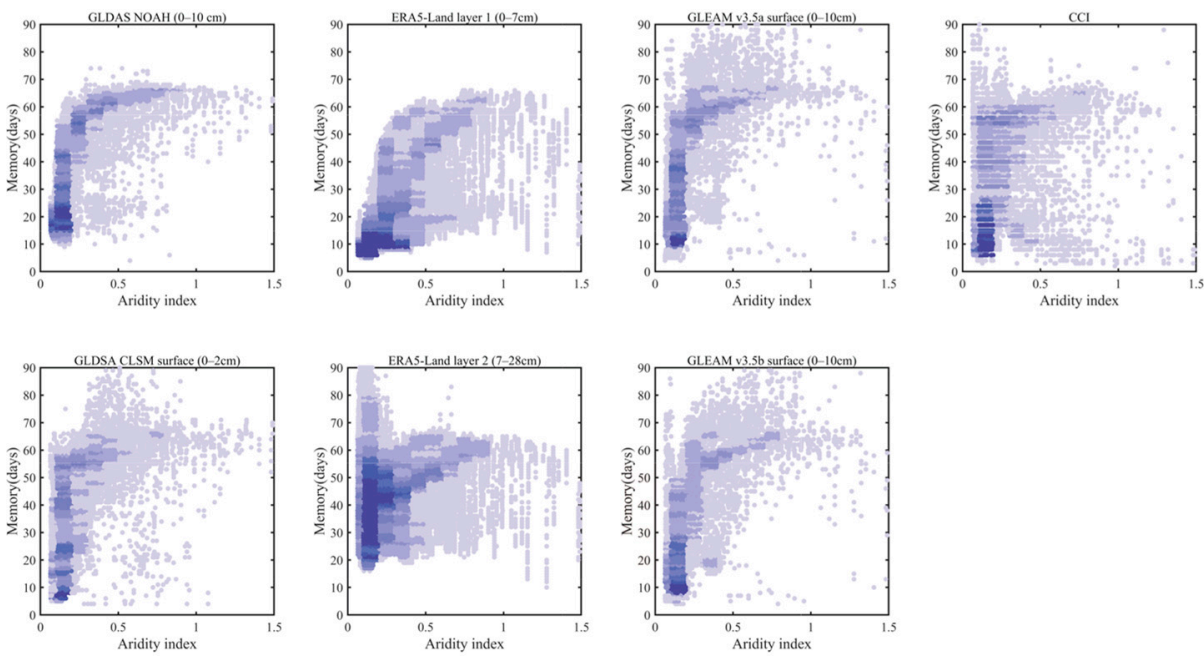

Figure 7. Scatterplots of surface SMP versus aridity index.

\subsubsection{Relationship with Vegetation Status}

Vegetation has a water-fixing effect. Vegetation characteristics such as vegetation coverage, type and root structure affect SM by changing the physical and chemical properties of soil and microbial communities. Vegetation also affects water evaporation and storage processes, controlling SM patterns indirectly. In addition, vegetation can affect redistribution of precipitation, thereby affecting land-air coupling and SMP. Vegetation changes are closely coupled with the hydrological system, especially in the water-limited 
ecosystem of Australia. Vegetation patterns affect the amount of water stored in the soil, and the vegetation index reflects the state of SM to a certain extent. Vegetation continuously absorbs water in the soil through the water potential gradient and then releases it into the atmosphere through transpiration. Vegetation transpiration is the main form of loss of SM. At the same time, the vegetation canopy has the effect of intercepting and redistributing precipitation [53], which significantly affects the water cycle. Therefore, vegetation is also an important factor affecting SMP. There is a significant positive correlation between surface SMP and EVI in Australia (Figure 8). Using EVI variation coefficient as a characterization of vegetation disturbance, the surface SMP increased with the increase of disturbance (Figure A6). A potential explanation is that large vegetation disturbances could be caused by agricultural activities such as continuous irrigation and film mulching, and other measures have resulted in a relatively stable SM-the surface SMP tends to be long then.
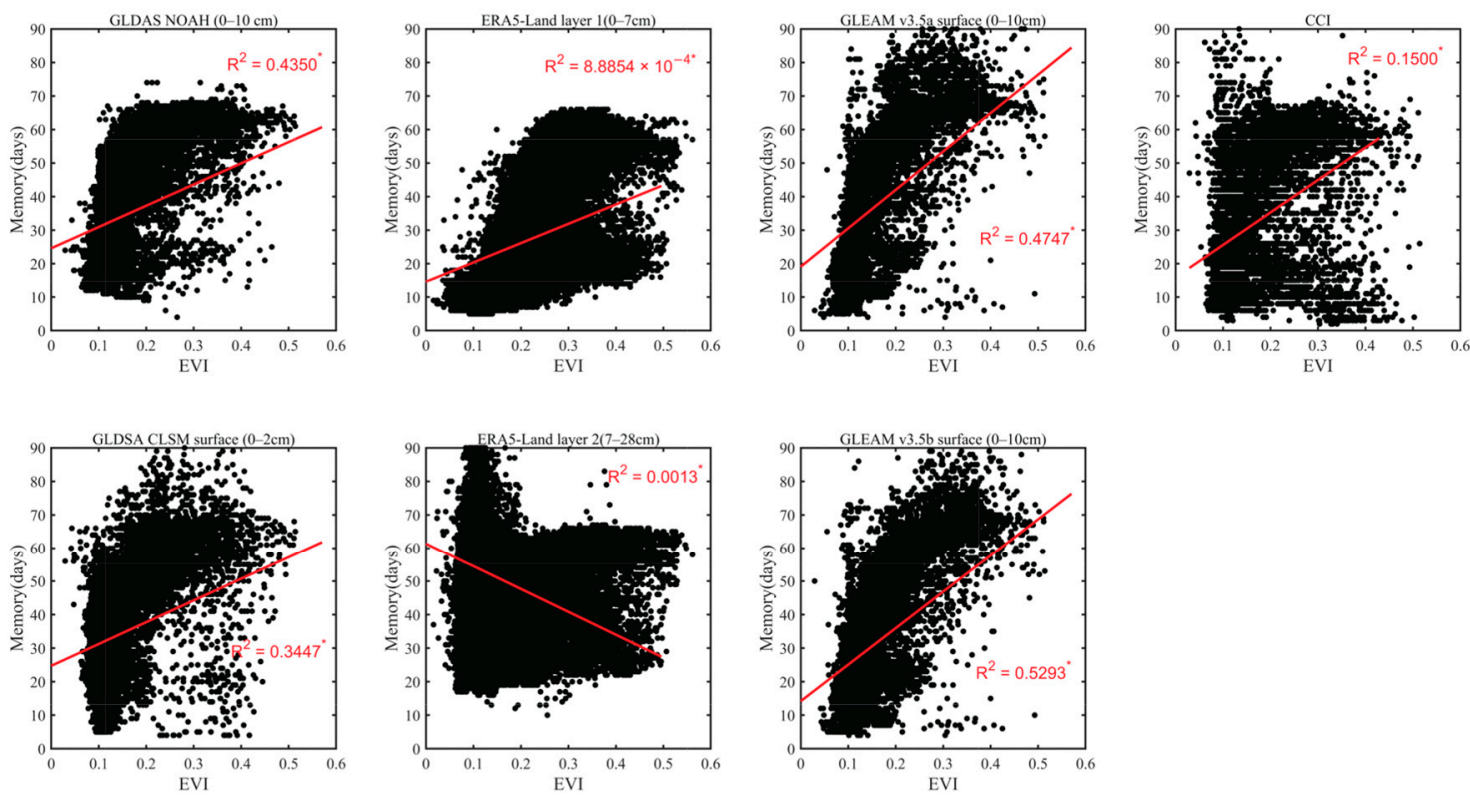

Figure 8. Same as Figure 6, but representing the scatterplots of surface SMP versus EVI. The red solid line is the linear fitting line.

There are significant differences in surface SMP under different vegetation (Table 4). Multiple SM showed that surface SMP under agricultural vegetation was the most durable, followed by that of forests. Surface SMP under grassland was the worst, and surface SMP under the savanna was slightly higher than that under shrublands. Consistent with the previous results, the surface SMP of ERA5-Land $(0-7 \mathrm{~cm})$ under different vegetation coverage was all underestimated (Table 4, Column 1). The surface SMP difference of CCI SM under different vegetation coverage was small. Meanwhile, surface SMP of grassland was lower than that of other vegetation indicated by all these datasets. In most SM data, surface SMP under grassland was lower than that of shrublands, while the surface SMP from GLDAS NOAH under shrublands was less than that of grassland, which indicated that the surface SMP from GLDAS NOAH under shrublands was underestimated. He et al. [54] believe that the longer cycle of vegetation-SM oscillation often occurs in woody biological communities, while the oscillation cycle of herbaceous vegetation land types is shorter. Although grassland is susceptible to drought, it has the ability to recover quickly [55]. This is consistent with the results of this study. 
Table 4. Surface SMP under different vegetation cover.

\begin{tabular}{|c|c|c|c|c|c|c|}
\hline Type & $\begin{array}{c}\text { ERA5-Land } \\
\text { Layer } 1 \\
(0-7 \mathrm{~cm})\end{array}$ & $\begin{array}{l}\text { GLDAS CLSM } \\
\text { Surface } \\
(0-2 \mathrm{~cm})\end{array}$ & $\begin{array}{l}\text { GLDAS } \\
\text { NOAH } \\
(0-10 \mathrm{~cm})\end{array}$ & $\begin{array}{c}\text { GLEAM v3.5a } \\
\text { Surface } \\
(0-10 \mathrm{~cm})\end{array}$ & $\begin{array}{c}\text { GLEAM v3.5b } \\
\text { Surface } \\
(0-10 \mathrm{~cm})\end{array}$ & $\begin{array}{l}\text { ESA CCI Soil } \\
\text { Moisture } \\
(<2 \mathrm{~cm})\end{array}$ \\
\hline Forest & 25.9 & 43.9 & 47.5 & 55.3 & 45.4 & 37.6 \\
\hline Savanna & 20.9 & 41.0 & 39.7 & 41.9 & 36.7 & 31.6 \\
\hline Shrubland & 15.8 & 37.2 & 27.4 & 37.5 & 31.2 & 32.6 \\
\hline Agriculture & 29.2 & 55.1 & 48.1 & 59.8 & 51.7 & 38.4 \\
\hline Grassland & 12.0 & 27.5 & 34.7 & 34.2 & 27.3 & 23.0 \\
\hline
\end{tabular}

\section{Conclusions}

In this study, we investigated the spatial-temporal characteristics and SMP over Australia, a very typical dryland region. For the comprehensiveness of the analysis, sites-based, remote-sensing and reanalysis-based SM datasets were used. At the same time, despite heterogeneity in landscape structure, precipitation, vegetation, and aridity conditions all had relative effects on SMP, and improvement of SM simulations in models still needs to take these factors into account. Precipitation and vegetation were also involved because precipitation is the main source of SM, and vegetation is sensitive to changes in surface SM in drylands.

Site observations and other SM data showed high correlation coefficients, indicating that these SM datasets were better in terms of average time change characteristics. These datasets coherently showed that the inter-annual fluctuations of SM were relatively large with some dry periods (2002-2010, 2013-2016) and wet periods (2011-2012).

The average spatial consistency over the years was very good, but in some lateral flow areas, different SM products showed hugely different spatial structures. The spatial distribution of change trends was quite different. These coefficients of variation of SM datasets were all generally decreased from northwest to southeast, however, a large coefficient of variation of EVI occurred in the southwest corner, the northeast (not coastal area) and the inflow areas.

SMP from calculated SM datasets had quite large differences compared with measurements. Meanwhile, little coherence was gotten among them, and the persistence of deep SM seemed to be significantly overestimated.

Author Contributions: Conceptualization, J.C. and T.C.; methodology, J.C. and T.C.; validation, J.C.; formal analysis, T.C. and R.G.; writing —original draft preparation, J.C. and X.C.; writing-review and editing, T.C. and Q.Y.; visualization, J.C.; supervision, T.C.; project administration, T.C and R.G.; funding acquisition, J.C. and T.C. All authors have read and agreed to the published version of the manuscript.

Funding: This study was financially supported by NSFC-UNEP Major International (Regional) Joint Research Project (No. 42161144003), the National Natural Science Foundation of China (No. 42130506, 31570464), the National Key R\&D Program of China (No. 2017YFB0504000), and the Postgraduate Research \& Practice Innovation Program of Jiangsu Province (No. KYCX21_0933).

Institutional Review Board Statement: Not applicable.

Informed Consent Statement: Not applicable.

Data Availability Statement: The in situ soil moisture data of OZNET is available at https:/ /www. geo.tuwien.ac.at/ (accessed on 21 April 2021). The ESA CCI soil moisture is available at http:/ /www. esa-soilmoisture-cci.org/ (accessed on 14 September 2020). The ERA5-Land dataset is available at https:/ / cds.climate.copernicus.eu/ (accessed on 11 March 2021). The GLEAM v3.5 data is available at https:/ / www.gleam.eu/ (accessed on 25 May 2021). The GLDAS soil moisture data of NOAH and CLSM is available at https:/ / disc.gsfc.nasa.gov / (accessed on 21 May 2021). The MODIS EVI dataset is available at https://ladsweb.modaps.eosdis.nasa.gov / (accessed on 28 March 2020). The CRU TS4.05 dataset of PET \& Precipitation is available at the https:/ / crudata.uea.ac.uk/ (accessed on 5 March 2021). The NVIS-MVGs V6.0 landcover dataset is available at http:/ /www.environment.gov. 
au/land/native-vegetation/national-vegetation-information-system/data-products (accessed on 18 August 2021). Precipitation dataset of TRMM 3B42 Daily is available at https: / / disc.gsfc.nasa.gov / (accessed on 24 June 2021). DEM of SRTM is available at https:/ / srtm.csi.cgiar.org/ (accessed on 7 June 2021).

Conflicts of Interest: The authors declare no conflict of interests.

\section{Abbreviations}

$\begin{array}{ll}\text { AC } & \text { autocorrelation coefficient } \\ \text { AI } & \text { aridity index } \\ \text { CV } & \text { coefficient of variation } \\ \text { EVI } & \text { enhanced vegetation index } \\ \text { ET } & \text { evapotranspiration } \\ \text { ISMN } & \text { International Soil Moisture Network } \\ \text { LSMs } & \text { land surface models } \\ \text { NVIS-MVGs } & \text { National Vegetation Information System-Main Vegetation Groups } \\ \text { OZNET } & \text { Ozark Network Communications } \\ \text { PET } & \text { potential evapotranspiration } \\ \text { PF } & \text { precipitation frequency } \\ \text { PI } & \text { precipitation intensity } \\ \text { SM } & \text { soil moisture } \\ \text { SMP } & \text { soil moisture persistence } \\ \text { TRMM } & \text { Tropical Rainfall Measuring Mission }\end{array}$

\section{Appendix A}

Table A1. Surface SMP calculated by multi-source surface SM datasets and in situ observational sites.

\begin{tabular}{|c|c|c|c|c|c|c|c|}
\hline & ISMN & $\begin{array}{c}\text { ERA5-Land } \\
\text { Layer } 1 \\
(0-7 \mathrm{~cm})\end{array}$ & $\begin{array}{c}\text { GLDAS } \\
\text { CLSM Surface } \\
(0-2 \mathrm{~cm})\end{array}$ & $\begin{array}{c}\text { GLDAS } \\
\text { NOAH } \\
(0-10 \mathrm{~cm})\end{array}$ & $\begin{array}{c}\text { GLEAM v3.5a } \\
\text { Surface } \\
(0-10 \mathrm{~cm})\end{array}$ & $\begin{array}{c}\text { GLEAM v3.5b } \\
\text { Surface } \\
(0-10 \mathrm{~cm})\end{array}$ & $\begin{array}{c}\text { ESA CCI } \\
(<2 \mathrm{~cm})\end{array}$ \\
\hline Canberra_Airport & 43 & $34(-9)$ & $56(13)$ & $35(-8)$ & $56(13)$ & $53(10)$ & $34(-9)$ \\
\hline Cooma_Airfield & 40 & $36(-4)$ & $27(-13)$ & $48(8)$ & $56(16)$ & $54(14)$ & $12(-28)$ \\
\hline Crawford & 54 & $46(-8)$ & $54(0)$ & $42(-12)$ & $64(10)$ & $61(7)$ & $42(-12)$ \\
\hline Ginninderra_K5 & 59 & $47(-12)$ & $55(-4)$ & $46(-13)$ & $64(5)$ & $62(3)$ & $36(-23)$ \\
\hline Griffith_Aerodrome & 42 & $29(-13)$ & $51(9)$ & $34(-8)$ & $43(1)$ & $38(-4)$ & $42(0)$ \\
\hline Hay_AWS & 27 & $38(11)$ & $50(23)$ & $36(9)$ & $56(29)$ & $44(17)$ & $47(20)$ \\
\hline Rochedale & 36 & $57(21)$ & - & $63(27)$ & $62(26)$ & - & $58(22)$ \\
\hline Waitara & 37 & $34(-3)$ & $33(-4)$ & $35(-4)$ & $53(16)$ & $52(15)$ & $43(6)^{\prime}$ \\
\hline West_Wyalong_Airfield & 47 & $43(-4)$ & $45(-2)$ & $43(-2)$ & $60(13)$ & $57(10)$ & $49(2)$ \\
\hline Yanco_Research_Station & 33 & $9(-24)$ & $16(-17)$ & $15(-18)$ & $36(3)$ & $36(3)$ & $36(3)$ \\
\hline Average & $41.8 \pm 9.6$ & $\begin{array}{c}37.3 \pm 12.8 \\
(-4.5 \pm 12.6)\end{array}$ & $\begin{array}{l}43.0 \pm 14.3 \\
(0.6 \pm 12.6)\end{array}$ & $\begin{array}{c}39.7 \pm 12.3 \\
(-2.1 \pm 13.4)\end{array}$ & $\begin{array}{c}55.0 \pm 9.1 \\
(13.2 \pm 9.2)\end{array}$ & $\begin{array}{l}50.8 \pm 9.4 \\
(8.3 \pm 6.8)\end{array}$ & $\begin{array}{c}39.9 \pm 12.1 \\
(-1.9 \pm 16.4)\end{array}$ \\
\hline
\end{tabular}



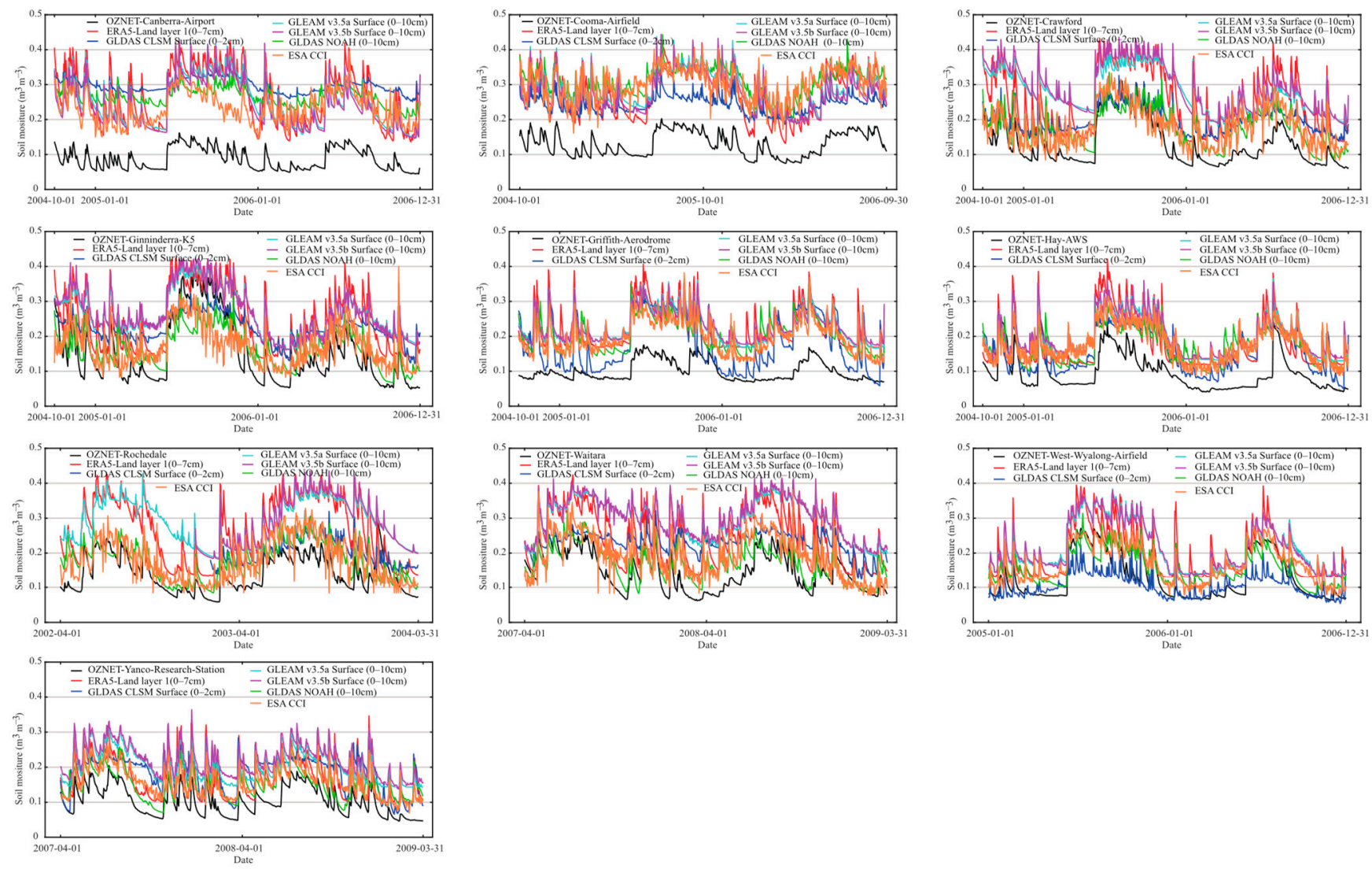

Figure A1. Time series comparisons of multiple SM products (surface) with in situ observational sites (dark) in the selected period.
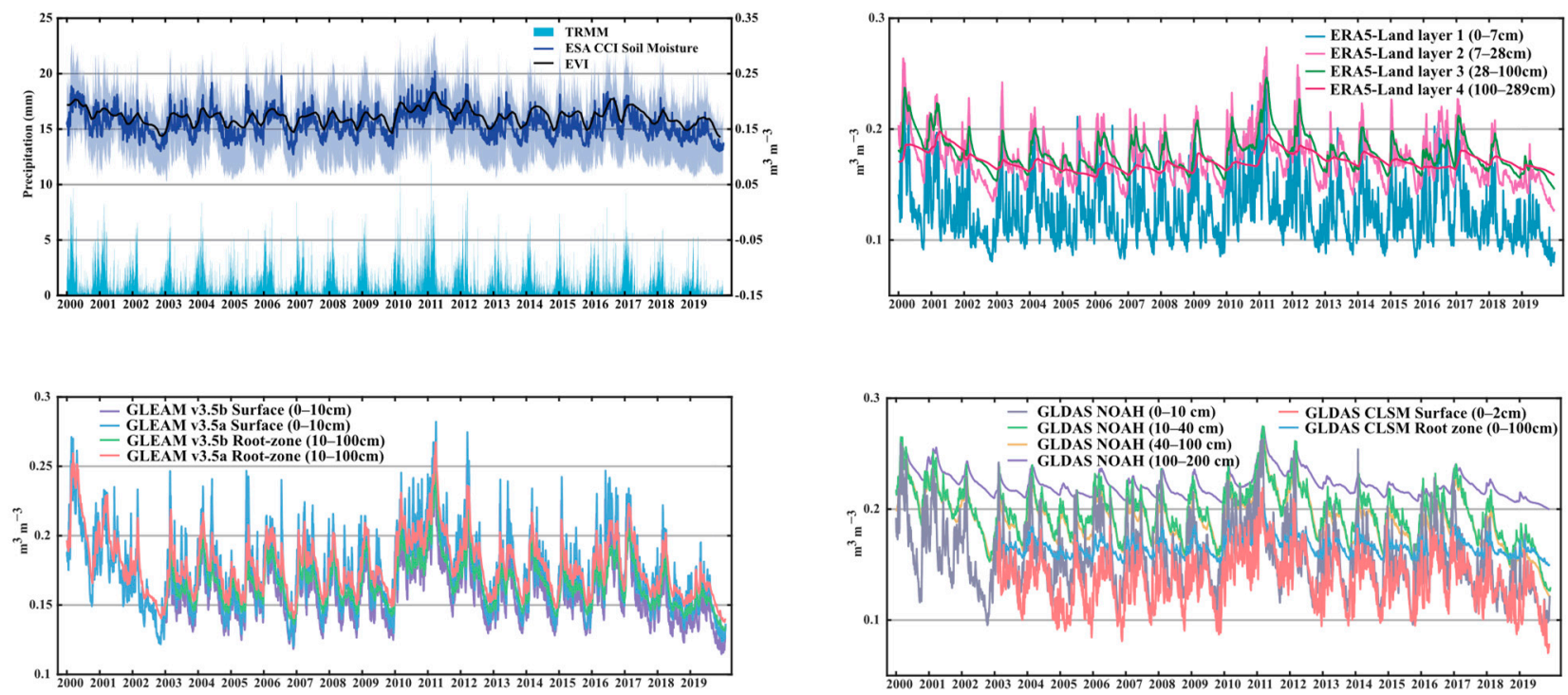

Figure A2. Time series of regional average multi-source SM, precipitation and EVI in Australia. 

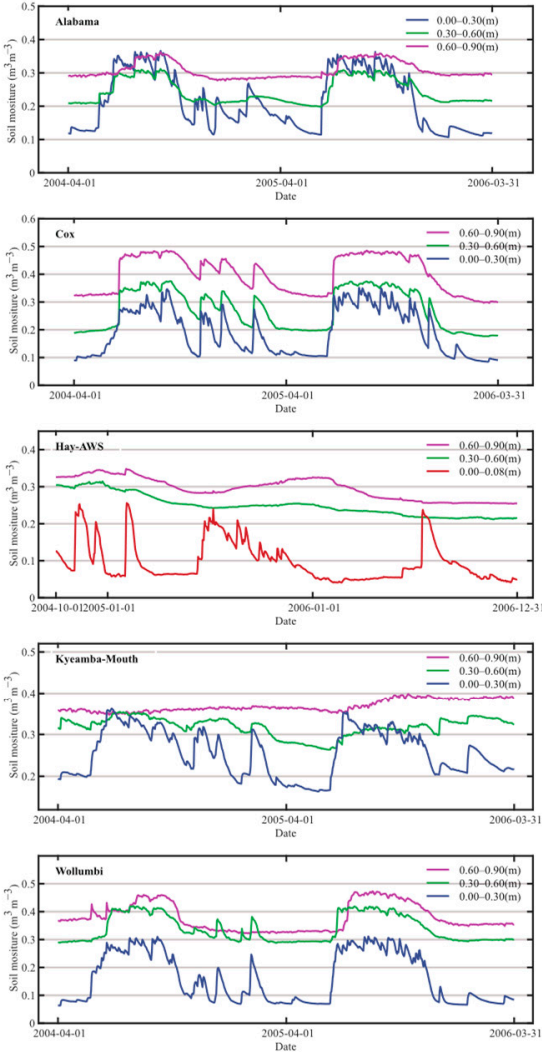
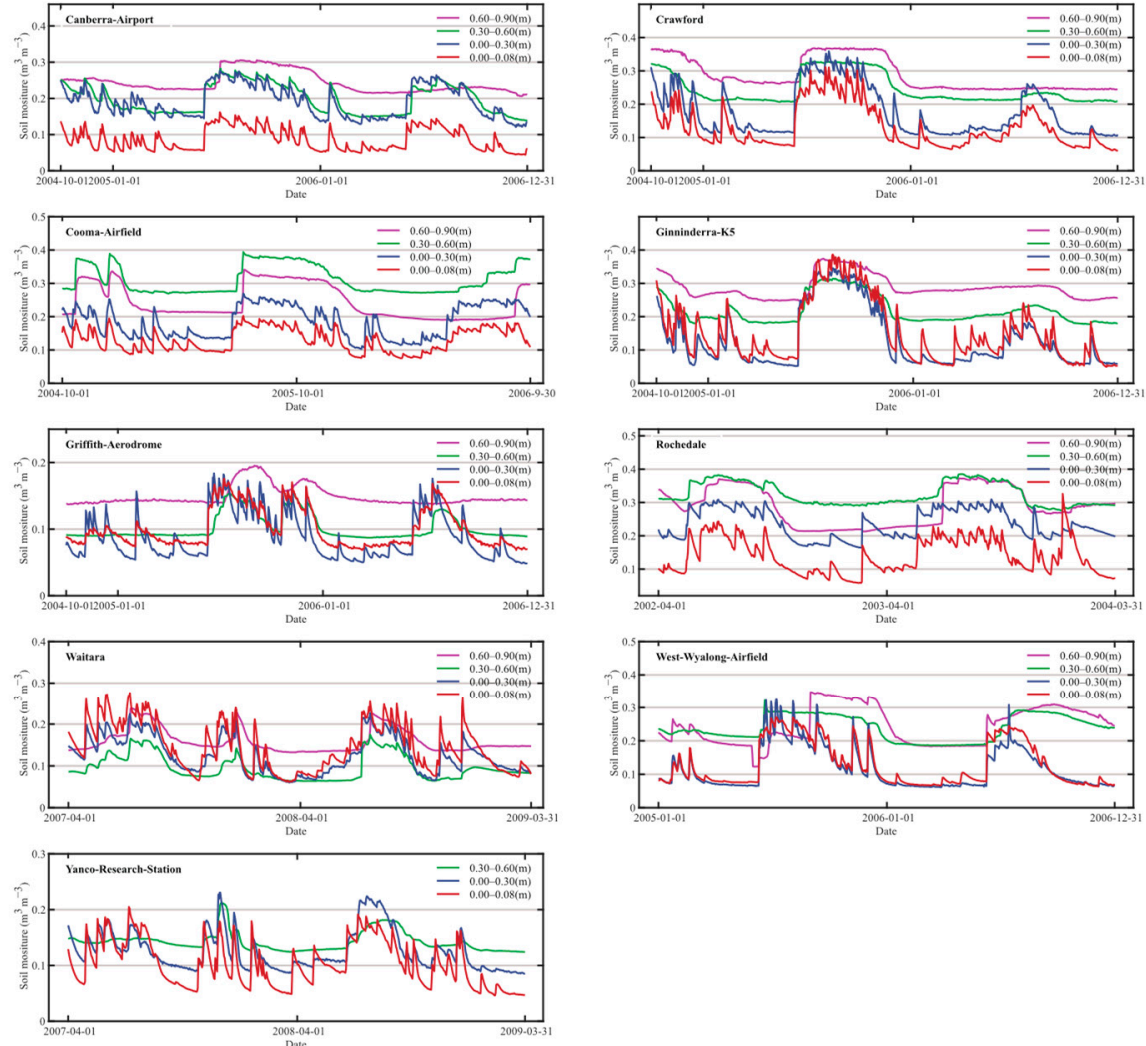

Figure A3. Time series of different depths in situ observational sites in the selected period.
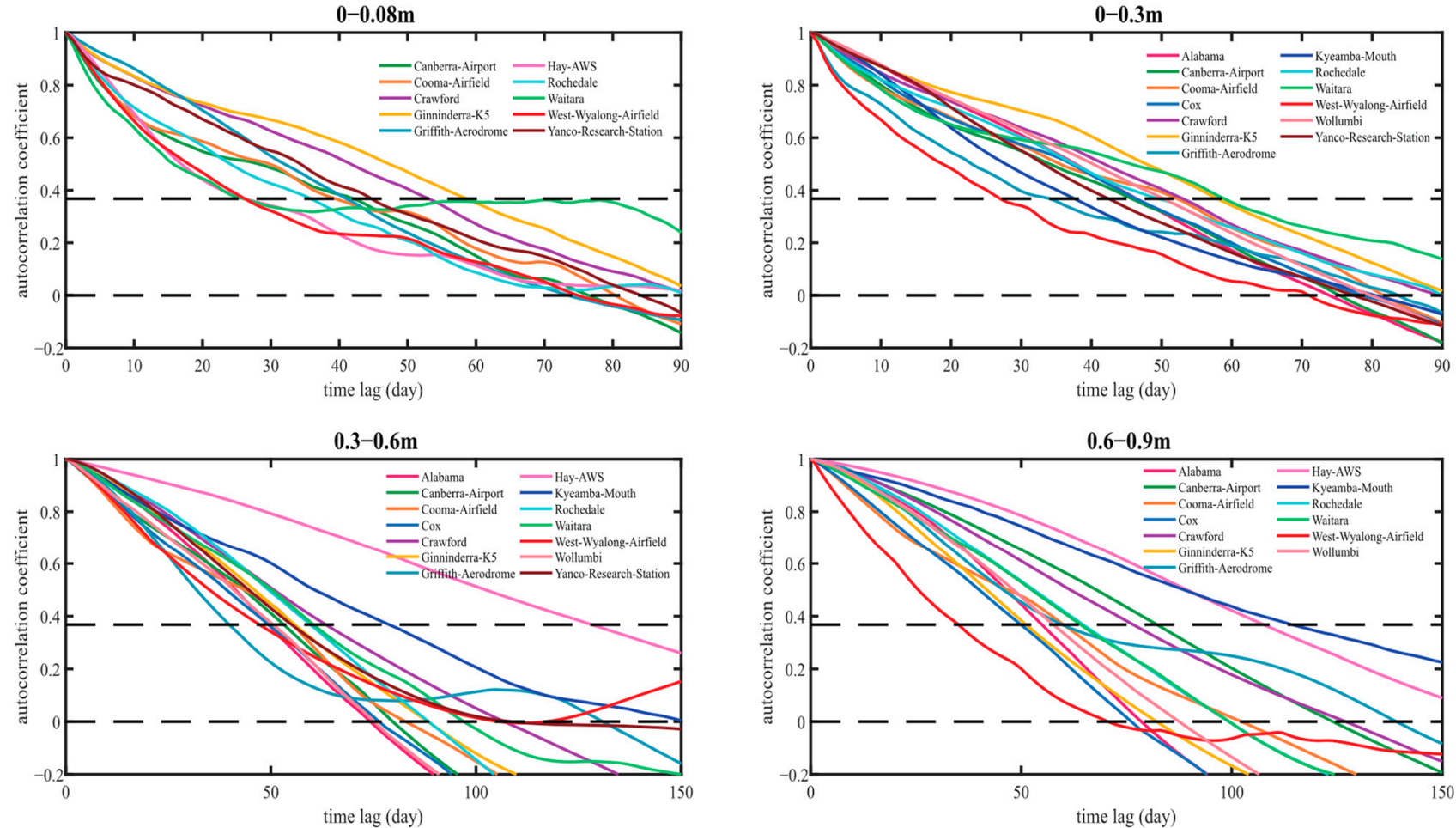

Figure A4. Autocorrelation graphs of different depths in situ observational sites in the selected period. 

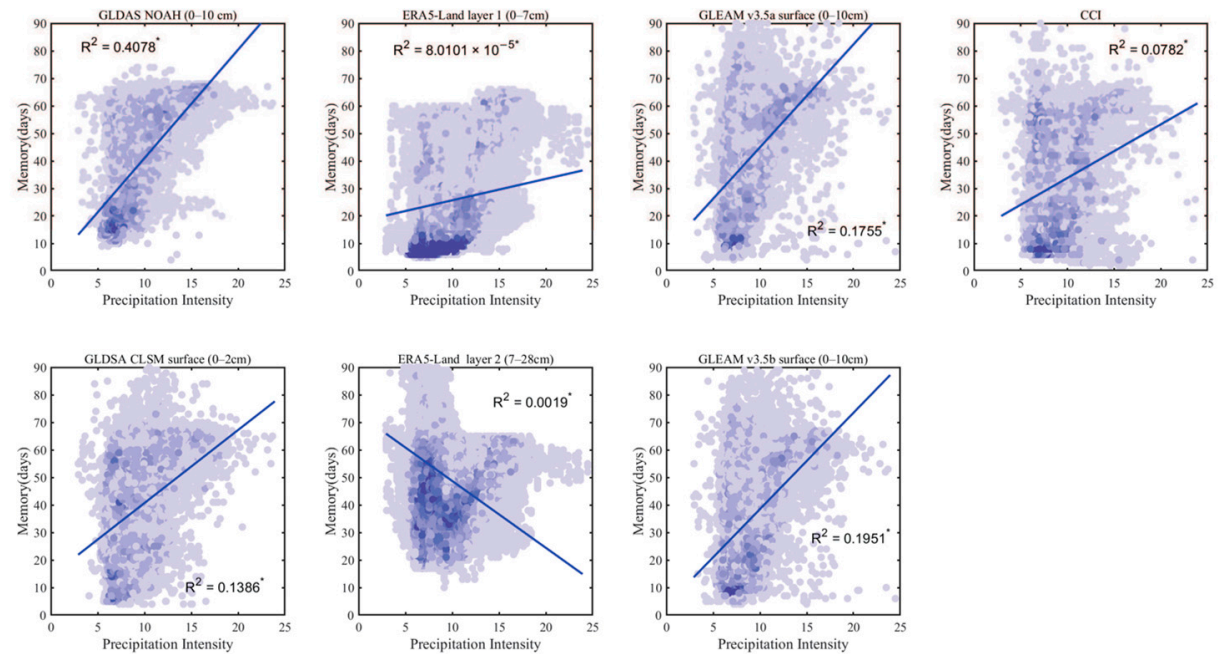

Figure A5. Same as Figure 6 but representing the scatterplots of surface SMP versus precipitation intensity.
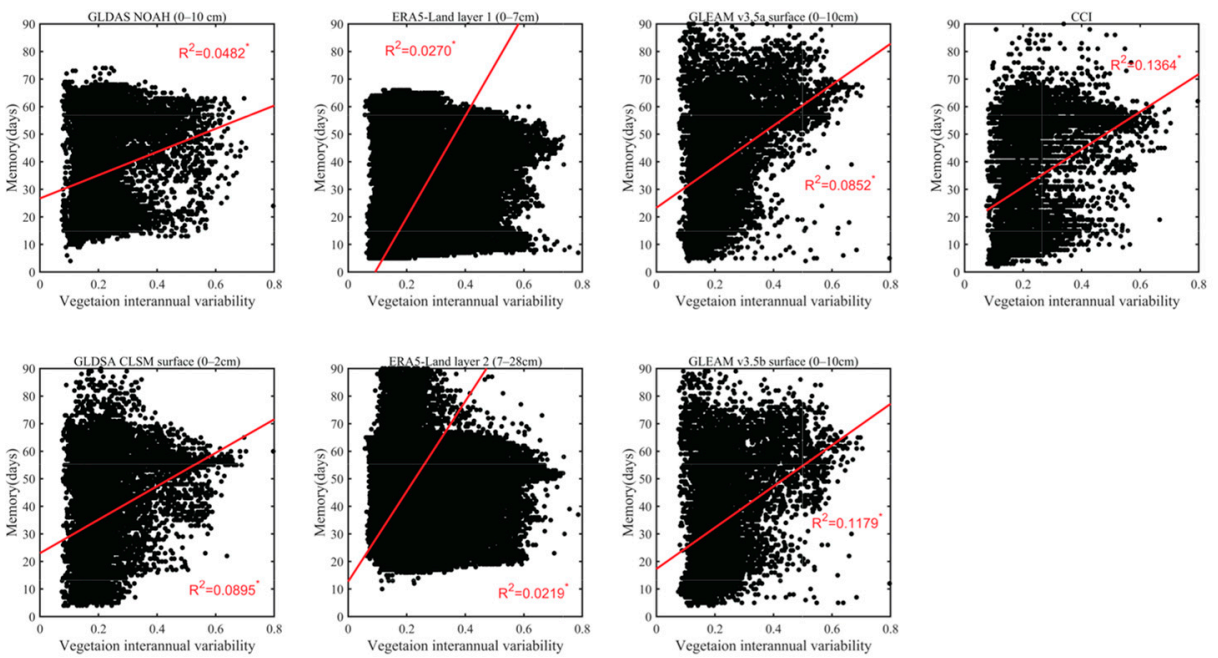

Figure A6. Scatterplots of surface SMP versus EVI coefficient of variation. Among them, $\mathrm{R}$ is the correlation coefficient, * indicating that the correlation coefficient passes the $95 \%$ significance test, the red solid line is the linear fitting line.

\section{References}

1. McColl, K.A.; He, Q.; Lu, H.; Entekhabi, D. Short-Term and Long-Term Surface Soil Moisture Memory Time Scales Are Spatially Anticorrelated at Global Scales. J. Hydrometeorol. 2019, 20, 1165-1182. [CrossRef]

2. Rebel, K.T.; de Jeu, R.A.M.; Ciais, P.; Viovy, N.; Piao, S.L.; Kiely, G.; Dolman, A.J. A global analysis of soil moisture derived from satellite observations and a land surface model. Hydrol. Earth Syst. Sci. 2012, 16, 833-847. [CrossRef]

3. Nicolai-Shaw, N.; Gudmundsson, L.; Hirschi, M.; Seneviratne, S. Long-term predictability of soil moisture dynamics at the global scale: Persistence versus large-scale drivers. Geophys. Res. Lett. 2016, 43, 8554-8562. [CrossRef]

4. Ahmadalipour, A.; Moradkhani, H.; Yan, H.; Zarekarizi, M. Remote Sensing of Drought: Vegetation, Soil Moisture, and Data Assimilation. In Remote Sensing of Hydrological Extremes. Springer Remote Sensing/Photogrammetry; Lakshmi, V., Ed.; Springer: Cham, Switzerland, 2017; pp. 121-149. [CrossRef]

5. Al-Yaari, A.; Wigneron, J.-P.; Dorigo, W.; Colliander, A.; Pellarin, T.; Hahn, S.; Mialon, A.; Richaume, P.; Moran, R.F.; Fan, L.; et al. Assessment and inter-comparison of recently developed/reprocessed microwave satellite soil moisture products using ISMN ground-based measurements. Remote Sens. Environ. 2019, 224, 289-303. [CrossRef]

6. Yan, Q.; Huang, W.; Jin, S.; Jia, Y. Pan-tropical soil moisture mapping based on a three-layer model from CYGNSS GNSS-R data. Remote Sens. Environ. 2020, 247, 111944. [CrossRef]

7. Qian, T.; Dai, A.; Trenberth, K.E.; Oleson, K.W. Simulation of Global Land Surface Conditions from 1948 to 2004 . Part I: Forcing Data and Evaluations. J. Hydrometeorol. 2006, 7, 953-975. [CrossRef]

8. Huang, Y.; Yu, X.; Li, E.; Chen, H.; Li, L.; Wu, X.; Li, X. A process-based water balance model for semi-arid ecosystems: A case study of psammophytic ecosystems in Mu Us Sandland, Inner Mongolia, China. Ecol. Model. 2017, 353, 77-85. [CrossRef] 
9. Elshorbagy, A.; Parasuraman, K. On the relevance of using artificial neural networks for estimating soil moisture content. J. Hydrol. 2008, 362, 1-18. [CrossRef]

10. Wen, H.; Brantley, S.L.; Davis, K.J.; Duncan, J.M.; Li, L. The Limits of Homogenization: What Hydrological Dynamics can a Simple Model Represent at the Catchment Scale? Water Resour. Res. 2021, 57. [CrossRef]

11. Mao, Y.; Crow, W.T.; Nijssen, B. A Unified Data-Driven Method to Derive Hydrologic Dynamics From Global SMAP Surface Soil Moisture and GPM Precipitation Data. Water Resour. Res. 2020, 56. [CrossRef]

12. Wang, Y.; Yang, J.; Chen, Y.; De Maeyer, P.; Li, Z.; Duan, W. Detecting the Causal Effect of Soil Moisture on Precipitation Using Convergent Cross Mapping. Sci. Rep. 2018, 8, 12171. [CrossRef] [PubMed]

13. Tuttle, S.E.; Salvucci, G.D. Confounding factors in determining causal soil moisture-precipitation feedback. Water Resour. Res. 2017, 53, 5531-5544. [CrossRef]

14. Tuttle, S.; Salvucci, G. Empirical evidence of contrasting soil moisture-precipitation feedbacks across the United States. Science 2016, 352, 825-828. [CrossRef]

15. Sun, S.; Wang, G. The complexity of using a feedback parameter to quantify the soil moisture-precipitation relationship. J. Geophys. Res. Earth Surf. 2012, 117, 11113. [CrossRef]

16. Eltahir, E.A.B. A Soil Moisture-Rainfall Feedback Mechanism: 1. Theory and observations. Water Resour. Res. 1998, 34, 765-776. [CrossRef]

17. Jacobs, E.M.; Bertassello, L.E.; Rao, P.S.C. Drivers of regional soil water storage memory and persistence. Vadose Zone J. 2020, 19, e20050. [CrossRef]

18. Kidron, G.J. Comparing overland flow processes between semiarid and humid regions: Does saturation overland flow take place in semiarid regions? J. Hydrol. 2021, 593, 125624. [CrossRef]

19. Chen, T.; de Jeu, R.; Liu, Y.; van der Werf, G.; Dolman, A. Using satellite based soil moisture to quantify the water driven variability in NDVI: A case study over mainland Australia. Remote Sens. Environ. 2014, 140, 330-338. [CrossRef]

20. Su, C.-H.; Zhang, J.; Gruber, A.; Parinussa, R.; Ryu, D.; Crow, W.T.; Wagner, W. Error decomposition of nine passive and active microwave satellite soil moisture data sets over Australia. Remote Sens. Environ. 2016, 182, 128-140. [CrossRef]

21. Dorigo, W.A.; Wagner, W.; Hohensinn, R.; Hahn, S.; Paulik, C.; Xaver, A.; Gruber, A.; Drusch, M.; Mecklenburg, S.; van Oevelen, P.; et al. The International Soil Moisture Network: A data hosting facility for global in situ soil moisture measurements. Hydrol. Earth Syst. Sci. 2011, 15, 1675-1698. [CrossRef]

22. Sandiford, M.; Lawrie, K.; Brodie, R.S. Hydrogeological implications of active tectonics in the Great Artesian Basin, Australia. Appl. Hydrogeol. 2020, 28, 57-73. [CrossRef]

23. Chen, T.; McVicar, T.R.; Wang, G.; Chen, X.; De Jeu, R.A.M.; Liu, Y.Y.; Shen, H.; Zhang, F.; Dolman, A.J. Advantages of Using Microwave Satellite Soil Moisture over Gridded Precipitation Products and Land Surface Model Output in Assessing Regional Vegetation Water Availability and Growth Dynamics for a Lateral Inflow Receiving Landscape. Remote Sens. 2016, 8, 428. [CrossRef]

24. Abram, N.J.; Henley, B.J.; Gupta, A.S.; Lippmann, T.J.R.; Clarke, H.; Dowdy, A.J.; Sharples, J.J.; Nolan, R.H.; Zhang, T.; Wooster, M.J.; et al. Connections of climate change and variability to large and extreme forest fires in southeast Australia. Commun. Earth Environ. 2021, 2, 1-17. [CrossRef]

25. Miralles, D.G.; Nieto, R.; McDowell, N.G.; Dorigo, W.; Verhoest, N.E.; Liu, Y.Y.; Teuling, A.; Dolman, A.; Good, S.P.; Gimeno, L. Contribution of water-limited ecoregions to their own supply of rainfall. Environ. Res. Lett. 2016, 11, 124007. [CrossRef]

26. Harris, R.M.B.; Beaumont, L.J.; Vance, T.R.; Tozer, C.R.; Remenyi, T.; Perkins-Kirkpatrick, S.E.; Mitchell, P.; Nicotra, A.; McGregor, S.; Andrew, N.R.; et al. Biological responses to the press and pulse of climate trends and extreme events. Nat. Clim. Chang. 2018, 8, 579-587. [CrossRef]

27. Dorigo, W.; Wagner, W.; Albergel, C.; Albrecht, F.; Balsamo, G.; Brocca, L.; Chung, D.; Ertl, M.; Forkel, M.; Gruber, A.; et al. ESA CCI Soil Moisture for improved Earth system understanding: State-of-the art and future directions. Remote Sens. Environ. 2017, 203, 185-215. [CrossRef]

28. Gruber, A.; Scanlon, T.; van der Schalie, R.; Wagner, W.; Dorigo, W. Evolution of the ESA CCI Soil Moisture climate data records and their underlying merging methodology. Earth Syst. Sci. Data 2019, 11, 717-739. [CrossRef]

29. Muñoz-Sabater, J.; Dutra, E.; Agustí-Panareda, A.; Albergel, C.; Arduini, G.; Balsamo, G.; Boussetta, S.; Choulga, M.; Harrigan, S.; Hersbach, H.; et al. ERA5-Land: A state-of-the-art global reanalysis dataset for land applications. Earth Syst. Sci. Data 2021, 13, 4349-4383. [CrossRef]

30. Li, B.; Rodell, M.; Kumar, S.; Beaudoing, H.K.; Getirana, A.; Zaitchik, B.F.; De Goncalves, L.G.; Cossetin, C.; Bhanja, S.; Mukherjee, A.; et al. Global GRACE Data Assimilation for Groundwater and Drought Monitoring: Advances and Challenges. Water Resour. Res. 2019, 55, 7564-7586. [CrossRef]

31. Rodell, M.; Houser, P.R.; Jambor, U.; Gottschalck, J.; Mitchell, K.; Meng, C.-J.; Arsenault, K.; Cosgrove, B.; Radakovich, J.; Arsenault, K.; et al. The Global Land Data Assimilation System. Bull. Am. Meteorol. Soc. 2004, 85, 381-394. [CrossRef]

32. Miralles, D.G.; Holmes, T.R.H.; De Jeu, R.A.M.; Gash, J.H.; Meesters, A.G.C.A.; Dolman, A.J. Global land-surface evaporation estimated from satellite-based observations. Hydrol. Earth Syst. Sci. 2011, 15, 453-469. [CrossRef]

33. Martens, B.; Gonzalez Miralles, D.; Lievens, H.; Van Der Schalie, R.; De Jeu, R.A.M.; Fernández-Prieto, D.; Beck, H.E.; Dorigo, W.A.; Verhoest, N.E.C. GLEAM v3: Satellite-based land evaporation and root-zone soil moisture. Geosci. Model Dev. 2017, 10, 1903-1925. [CrossRef] 
34. Harris, I.; Osborn, T.J.; Jones, P.; Lister, D. Version 4 of the CRU TS monthly high-resolution gridded multivariate climate dataset. Sci. Data 2020, 7, 1-18. [CrossRef] [PubMed]

35. Hulme, M. Recent Climatic Change in the World's Drylands. Geophys. Res. Lett. 1996, 23, 61-64. [CrossRef]

36. Huang, J.; Li, Y.; Fu, C.; Chen, F.; Fu, Q.; Dai, A.; Shinoda, M.; Ma, Z.; Guo, W.; Li, Z.; et al. Dryland climate change: Recent progress and challenges. Rev. Geophys. 2017, 55, 719-778. [CrossRef]

37. Xu, H.; Wang, X.; Zhao, C.; Yang, X. Assessing the response of vegetation photosynthesis to meteorological drought across northern China. Land Degrad. Dev. 2021, 32, 20-34. [CrossRef]

38. Huffman, G.J.; Bolvin, D.T.; Nelkin, E.J.; Wolff, D.B.; Adler, R.F.; Gu, G.; Hong, Y.; Bowman, K.P.; Stocker, E.F. The TRMM Multisatellite Precipitation Analysis (TMPA): Quasi-Global, Multiyear, Combined-Sensor Precipitation Estimates at Fine Scales. J. Hydrometeorol. 2007, 8, 38-55. [CrossRef]

39. Eamus, D.; Huete, A.; Cleverly, J.; Nolan, R.; Ma, X.; Tarin, T.; Santini, N. Mulga, a major tropical dry open forest of Australia: Recent insights to carbon and water fluxes. Environ. Res. Lett. 2016, 11, 125011. [CrossRef]

40. Delworth, T.; Manabe, S. The Influence of Potential Evaporation on the Variabilities of Simulated Soil Wetness and Climate. J. Clim. 1988, 1, 523-547. [CrossRef]

41. Greve, P.; Orlowsky, B.; Mueller, B.; Sheffield, J.; Reichstein, M.; Seneviratne, S. Global assessment of trends in wetting and drying over land. Nat. Geosci. 2014, 7, 716-721. [CrossRef]

42. Deng, Y.; Wang, S.; Bai, X.; Luo, G.; Wu, L.; Chen, F.; Wang, J.; Li, C.; Yang, Y.; Hu, Z.; et al. Vegetation greening intensified soil drying in some semi-arid and arid areas of the world. Agric. For. Meteorol. 2020, 292-293, 108103. [CrossRef]

43. McColl, K.A.; Alemohammad, S.H.; Akbar, R.; Konings, A.G.; Yueh, S.; Entekhabi, D. The global distribution and dynamics of surface soil moisture. Nat. Geosci. 2017, 10, 100-104. [CrossRef]

44. McColl, K.A.; Wang, W.; Peng, B.; Akbar, R.; Gianotti, D.J.S.; Lu, H.; Pan, M.; Entekhabi, D. Global characterization of surface soil moisture drydowns. Geophys. Res. Lett. 2017, 44, 3682-3690. [CrossRef]

45. IPCC. Climate Change 2021: The Physical Science Basis. Contribution of Working Group I to the Sixth Assessment Report of the Intergovernmental Panel on Climate Change; Masson-Delmotte, V., Zhai, P., Pirani, A., Connors, S.L., Péan, C., Berger, S., Caud, N., Chen, Y., Goldfarb, L., Gomis, M.I., et al., Eds.; Cambridge University Press: Cambridge, UK, 2021; in press.

46. Xie, Z.; Huete, A.; Cleverly, J.; Phinn, S.; McDonald-Madden, E.; Cao, Y.; Qin, F. Multi-climate mode interactions drive hydrological and vegetation responses to hydroclimatic extremes in Australia. Remote Sens. Environ. 2019, 231, 111270. [CrossRef]

47. Xie, Z.; Huete, A.; Restrepo-Coupe, N.; Ma, X.; Devadas, R.; Caprarelli, G. Spatial partitioning and temporal evolution of Australia's total water storage under extreme hydroclimatic impacts. Remote Sens. Environ. 2016, 183, 43-52. [CrossRef]

48. Ivanov, V.Y.; Bras, R.L.; Vivoni, E.R. Vegetation-hydrology dynamics in complex terrain of semiarid areas: 1. A mechanistic approach to modeling dynamic feedbacks. Water Resour. Res. 2008, 44. [CrossRef]

49. Cook, B.I.; Bonan, G.B.; Levis, S. Soil Moisture Feedbacks to Precipitation in Southern Africa. J. Clim. 2006, 19, 4198-4206. [CrossRef]

50. Li, X.-Y. Mechanism of coupling, response and adaptation between soil, vegetation and hydrology in arid and semiarid regions. Sci. Sin. Terrae 2011, 41, 1721-1730.

51. Ford, T.W.; Quiring, S.M.; Thakur, B.; Jogineedi, R.; Houston, A.; Yuan, S.; Kalra, A.; Lock, N. Evaluating Soil MoisturePrecipitation Interactions Using Remote Sensing: A Sensitivity Analysis. J. Hydrometeorol. 2018, 19, 1237-1253. [CrossRef]

52. Cheng, Y.; Chan, P.W.; Wei, X.; Hu, Z.; Kuang, Z.; McColl, K.A. Soil Moisture Control of Precipitation Reevaporation over a Heterogeneous Land Surface. J. Atmos. Sci. 2021, 78, 3369-3383. [CrossRef]

53. Guswa, A.J. Canopy vs. Roots: Production and Destruction of Variability in Soil Moisture and Hydrologic Fluxes. Vadose Zone J. 2012, 11, vzj2011.0159. [CrossRef]

54. He, Q.; Yue, S.; Lu, H.; Liu, Z.; Huang, X.; Entekhabi, D. Identifying Terrestrial Vegetation-Soil Moisture Oscillation from Satellite Observations. In Proceedings of the IGARSS 2020-2020 IEEE International Geoscience and Remote Sensing Symposium, Waikoloa, HI, USA, 26 September-2 October 2020; pp. 4570-4573.

55. Aeruo, G.; Velicogna, I.; Kimball, J.S.; Du, J.; Kim, Y.; Colliander, A.; Njoku, E. Satellite-observed changes in vegetation sensitivities to surface soil moisture and total water storage variations since the 2011 Texas drought. Environ. Res. Lett. 2017, 12, 054006. [CrossRef] 